\title{
Klášter Hradiště ve sporu o domašovský les. Př́íspěvek k dějinám mezního práva ve stř̌edověku
}

\author{
Jakub Razim
}

Právnická fakulta, Univerzita Palackého v Olomouci

Kontaktni email: jakub.razim@post.cz

Hradiště Monastery in the Dispute over the Domašov Forest: A Study on the History of Law of Borders in the Middle Ages

\begin{abstract}
:
In a survey into the legal history of the Premonstratensian monastery Hradiště near Olomouc, in which I tried to uncover the details of the border dispute over church land near Domašov around 1220, I placed under a microscope the forged document CDB II 376, which is the result of numerous counterfeiting activities taking place in Hradiště scriptorium since the second half of the 13th century. The diplomatic material of the ancient Moravian foundation has been an interesting subject of investigation both because it is famous for its verbosity, with which it describes legal realities, and because the monastery, as a colonizer, had constantly been involved in conflicts with the surrounding landowners making its destiny an excellent springboard for the research of the Law of Borders in the Middle Ages. However, in order to shed light on one of the long-neglected aspects of medieval legal life that I encounter here, it was necessary to test the factual accuracy of CDB II 376. A comparison with chartes and records on the practices of the Law of Borders, which have been preserved in our region since the Přemyslid period, was chosen as a tool of source criticism. The findings I have reached lead to the conclusion that the forgery fits well into our general knowledge of public administration in the first decades of the 13th century. After all, the justification of the territorial aspirations substantiated in writing had to be acknowledged also by the opponent of the Premonstratensian monastery, Albert of Šternberk.
\end{abstract}

Key words:

Middle Ages; Moravia; Hradiště monastery; legal history; law of borders; legal ritual; charters; forgery; perambulation

\section{Klíčová slova:}

středověk; Morava; klášter Hradiště; právní dějiny; mezní právo; právní rituál; listiny; falzum; objezd; ochoz

DOI: $10.14712 / 2464689 X .2020 .29$ 


\section{Hradišt'ský klášter a jeho falza}

Následující řádky budou věnovány starším dějinám mezního práva, jehož přesnější kontury se v našem listinném materiálu začínají rýsovat od 12 . století. ${ }^{1}$ Úprava měla zprvu obyčejový ráz a silný rituální náboj, přičemž její těžiště spočívalo v ochraně hranic nemovitého majetku. Na pergamen bylo mezní právo zaznamenáváno teprve druhotně a dlouho jen výběrově. $Z$ torzovitých pramenů lze přesto nabýt dojmu, že sestávalo hlavně z procesních předpisů. Ty měly za cíl bud' předcházet sousedským hádkám o pozemky, nebo dosáhnout jejich trvalejš́ího řešení, at' už soudní, event. mimosoudní cestou. ${ }^{2} \mathrm{Kdy}$ koliv se půda stávala předmětem majetkoprávní dispozice, sporu, nebo obnovy hraničních ukazatelů, praktiky více či méně pravidelné, avšak doložitelné lépe až pro raný novověk, ${ }^{3}$ bylo zvykem uspořádat komisionální obhlídku, jejímž posláním bylo stanovit hranici př́imo v terénu. ${ }^{4}$ Celá akce se odbývala za př́ítomnosti úředních hodnostářu a za př́sného lpění na obřadných formalitách. Podle způsobu, jakým se účastníci z místa na místo přepravovali, hovoříme pak někdy o objezdu, jindy o ochozu.

Třebaže bylo v literatuře vícekrát poukázáno na význam rituálního vyměřování pozemkových hranic v životě středověkého člověka ${ }^{5}$ a i když základy pro jeho výzkum položila již historiografie 19 . století, ${ }^{6}$ postupem doby ztratilo mezní právo na přitažlivosti, načež se ocitlo zcela ve stínu jiných právněhistorických témat. ${ }^{7}$ Příčinu jeho ústupu ze slávy ale nelze spatřovat ve skutečnosti, že by pole bádání bylo zcela vyčerpáno a nemělo více co nabídnout. Opak je pravdou, jak se pokusíme demonstrovat na historii kláštera Hradiště u Olomouce, starobylé rodové fundace moravských Přemyslovců, která svými počátky sahá do let 1077-1078. ${ }^{8}$ Benediktinské opatství, které bylo v polovině 12 . století osazeno premonstráty, se skvěle hodí za výzkumný objekt pro naše účely. Zaprvé, rozptýlené majet-

1 O pramenech KAPRAS, J. Mezní přísaha v českém právu. Sbornikk věd právních a státních, 1915, roč. 15, s. 286-298, zde s. 287 a násl; TÝŽ. Der altböhmische Grenzeid im Grabe unter dem Rasen. Ein Beitrag zur Geschichte des Ordalwesens. Zeitschrift für vergleichende Rechtswissenschaft, 1916, roč. 34, s. 283-322, zde s. 286 a násl. Za obětavé rady a pomoc při psaní bych rád na tomto místě poděkoval Doc. Daliboru Havlovi a Dr. Lukášovi Führerovi z Pracoviště Českého diplomatáře FF MU. Nemenší dík patří ale i Centru pro studium středověku FF UK, s jehož podporou článek vznikl.

2 Hlavní zaměření mezního práva vystihli KLABOUCH, J. - PROCHÁZKA, V. Předpisy a obyčeje mezního práva v životě českého venkovského lidu v 17. a 18. století. Český lid, 1956, roč. 43, č. 4, 158-162, zde s. 158, 159. Najdeme ho ale už v klasické práci BADER, K. S. Der schwäbische Untergang. Studien zum Grenzrecht und Grenzprozeß im Mittelalter. Freiburg im Breisgau: Waibel, 1933, s. 27 a násl., kde autor klade vedle sebe „Grenzschutz“ a „Grenzstreit“.

3 KLABOUCH - PROCHÁZKA, $c . d$.

4 Srv. GRIMM, J. Deutsche Grenzalterthümer. In: TÝŽ. Kleinere Schriften II. Berlin: Ferd. Dümmlers Verlagsbuchhandlung, 1865, s. 30-74, zde s. 61-62; ERBEN, W. Deutsche Grenzaltertümer aus den Ostalpen. Zeitschrift der Savigny-Stiftung für Rechtsgeschichte. Germanistische Abteilung, 1922, Jhrg. 43, s. 1-65, zde s. 54

5 Připomeňme záslužnou studii KINCL, J. Dva testamenty šlechtice Kojaty. Acta Universitatis Carolinae Iuridica, 1987, roč. 3, s. 301-320, zde s. 305 a v pozn.

6 Ze specializovaných příspěvků JIREČEK, H. O soudu mezním dle práva českého a moravského. Časopis Musea Království českého, 1858, roč. 32, č. 2, s. 171-186; BRANDL, V. Staročeské právo mezní. Právník, 1869, roč. 8, s. 117-127, 155-166.

7 Pomineme-li stručný, deskriptivní přehled JANIŠ, D. - ŠENKÝŘOVÁ, J. Hranice statků a pozemků: jejich zachycení v písemných (právních) pramenech. Archaeologia historica, 2004, roč. 29, č. 1, s. 193-202.

$8 \quad$ FOLTÝN, D. a kol. Encyklopedie moravských a slezských klášterů. Praha: Libri, 2005, s. 513 a nás1. s literaturou. K založení fundace dále WIHODA, M. Benediktinská kapitola v dějinách kláštera Hradisko u Olomouce. In: JAN, L. - OBŠUSTA, P. (eds.). Ve stopách sv. Benedikta. Sborník př́spěvků z konference 
kové vybavení předurčovalo klášter do role pozemkové vrchnosti a bylo to právě důsledné hájení vrchnostenských práv, které vytvářelo třecí plochy mezi církevním ústavem a jeho sousedy, podílejícími se souběžně na středověkém osídlovacím procesu. ${ }^{9}$ Zadruhé, premonstráti z Hradiště po sobě zanechali bohatý diplomatický materiál, jehož obecnou předností je podrobné líčení právních záležitostí kláštera. ${ }^{10}$ Zároveň je v něm zachycen větší počet mezních sporů, vedených mnichy a jejich opatem v průběhu 13. století. ${ }^{11}$

Nevýhodou naopak je, že jen zlomek hradišt'ských listin z doby přemyslovské se dochoval v originále a že musíme začasté vzít za vděk falzy, jejichž vzájemný poměr a výpovědní hodnota vyvolávají mezi historiky kontroverze. Jak známo, působila v Hradišti u Olomouce falzátorská dílna, navazující na starší písařskou školu ${ }^{12}$ a prožívající svůj rozkvět ve druhé polovině 13 . století. ${ }^{13}$ Motivy pro zdejší rozsáhlou padělatelskou činnost bývají spojovány s rostoucí konkurencí na kolonizačním území, kde měl premonstrátský klášter své hmotné zájmy, avšak jeho vlastnickým nárokům se ne vždy dostávalo odpovídajícího písemného zajištění. ${ }^{14} \mathrm{Z}$ klášterního skriptoria vzešla nejspíš ze stejného důvodu i listina na domašovský les, rozprostírající se v blízkosti moravského Šternberka, jehož šlechtičtí držitelé se po generace svářeli s Hradištěm o majetky. ${ }^{15}$ Písemnost budeme pro jednoduchost nazývat CDB II 376 podle edice, s níž se běžně pracuje. Za bližší pozornost stojí proto, že přináší cenné detaily o našem mezním právu v „předkodifikačním“ období, které je skoupé na právní památky. Po stránce juristické lze znění listiny CDB II 376 shrnout do tří bodů: Poučit se tu můžeme o soudním procesu na zemském právu, o úředním vytýčení hranice mezi spornými pozemky a o listinném potvrzení ze strany zeměpána, které směřovalo k dosažení větší právní jistoty.

Pramen byl několikrát edičně zpř́stupněn, naposledy a doposud nejzdařileji ve Friedrichově Codexu, v němž je CDB II 376 otištěno s kritickým aparátem a opatřeno struč-

Středověké kláštery v zemích Koruny české konané ve dnech 24.-25. května 2001 v Třebiči. Brno: Matice moravská, 2002, s. 29-38.

9 Více o pozemkové výbavě ELBEL, P. Hospodářské zázemí kláštera Hradiště u Olomouce v 11. a 12. století. In: JAN - OBŠUSTA (eds.). c. d., s. 39-56.

10 ŠEBÁNEK, J. - DUŠKOVÁ, S. Česká listina doby přemyslovské 1 (Listina nižších feudálů duchovních; Listina feudálů světských). Sborník archivních prací, 1956, roč. 6, č. 1, s. 136-211, zde s. 187-188.

11 Srv. např. PACLÍK, J. Diplomatický príspěvek k otázkám hradištského klášterního velkostatku ve 2. polovině 13. století (Diplomová práce FF MU). Brno, 1954, s. 72 a nás1.; HOSÁK, L. Historický místopis střední a severni Moravy. Okres olomoucký, okres prostějovský. Olomouc: Krajské nakladatelství, 1959, s. 27-28.

12 HAVEL, D. K benediktinskému skriptoriu v Klášterním Hradisku u Olomouce ve 12. století: Metodická sonda. In: Campana - codex - civitas. Miroslao Flodr octogenario. Brno: Archiv města Brna, 2009, s. $136-176$.

13 Ze starších prací zejm. TEIGE, J. Zpráva o pramenech dějin kláštera Hradišt'ského u Olomouce (až do r. 1300). Zvláštni otisk z Věstniku královské české Společnosti nauk v Praze. Praha: Královská Česká Společnost Nauk, 1893; PINKAVA, V. O některých podvržených listinách kláštera hradišt'ského. Časopis Matice moravské, 1909, roč. 33, č. 4, 392-400. Bilanci výzkumu mají ŠEBÁNEK, J. - DUŠKOVÁ, S. Listina v českém státě doby Václava I. (u nižšich feudálů a u měst). Praha: Nakladatelství Československé akademie věd, 1963, s. 60 a v pozn.

14 PACLÍK, c. d., s. 74; HRABĚTOVÁ, I. Archív kláštera hradišt’ského (Disertační práce FF MU). Brno, 1969, s. 14-16; ŠVÁBENSKÝ, M. E 55 - Premonstráti Klášterni Hradisko (1078) 1200-1784 (1800). Katalog, 1. svazek. Úvod. Listiny. Úřední knihy a rukopisy. Brno, 1978, s. 5. Strojopis je uložen v badatelně Moravského zemského archivu.

15 Přehledně HRUBÝ, F. Severní Morava v dějinách. Brno: Družstvo Moravského kola spisovatelů, 1947, s. 60 a násl. 
ným paleograficko-diplomatickým rozborem. ${ }^{16}$ Protože se originál nezachoval, nezbylo vydavateli, než užít mladšího opisu ze 17. století, zařazeného do historického díla barokního učence a člena premonstrátského řádu Michaela Siebenaichera (1642-1680). ${ }^{17}$ Až později v 50. letech 20. století byl Karlem Dolistou objeven v Knihovně Národního muzea v Budapešti nejstarší kopiář premonstrátské kanonie Hradiště. ${ }^{18}$ Odtud bral Siebenaicher inspiraci pro vypsání klášterních dějin a odtud převzal i listinu, která pojednávala o mezním sporu, jehož meritem byl les u Domašova. ${ }^{19}$ Rukopis, započatý mezi léty 1418-1432, nachází se nyní v archivu převorství v mad'arské Csorne. Jelikož se prokázalo, že jeho studium může rozhojnit naše poznatky o diplomatické produkci kláštera v Hradišti, dalo by se očekávat, že vrhne nové světlo i na domašovský př́ipad. Přesto srovnání kopiáře s Friedrichovou edicí neprrináší žádný převratný výsledek. Vedle podružných odchylek ve slovosledu, krácení slov a psaní vlastních jmen můžeme zaznamenat rozdíl toliko v datační formuli.

Než ale postoupíme kupředu, musíme se zrovna u datace CDB II 376 zastavit. Problém, na který narážíme, je spletitější, než se může zdát ze zběžného nahlédnutí do edice. V čem tkví? Oba opisy, jak kopiářový, tak Siebenaicherův, vykazují dodatečné písařské opravy v údaji o vročení. U prvního je dopsáno ř́mskými číslicemi „XX“ při okraji řádku za „Mํ $\mathrm{CC}^{\circ}$. U druhého je datum „1220“ přepsáno na „1225“. Provedené změny komplikují práci s pramenným textem, a proto není divu, že se novodobí vydavatelé rozcházejí v jeho umístění na časové ose. Kde se Antonín Boček ${ }^{20}$ s Karlem Jaromírem Erbenem ${ }^{21}$ vyslovili pro rok 1215 a kde ještě Gustav Friedrich usuzoval na rok 1220, ${ }^{22}$ čímž se odchýlil od dřívějšího mínění svého a svých předchůdců, tam se nyní Pavla Švomová pod dojmem kopiáře z Csorne přiklání k číslovce 1205 a od přípisku „XX“ odhlížíi. ${ }^{23}$

Rok 1225 můžeme hned vyloučit, poněvadž Vladislav Jindřich, k němuž se listina hlásí jako ke svému vydavateli a kterého si v Hradišti považovali, majíce jej za obzvláštního příznivce mnišské komunity, zemřel roku $1222 .{ }^{24}$ Friedrich ve své edici přesvědčivě dovozuje, že pětka na konci letopočtu je výsledkem nekompetentní redakční práce, jdoucí

16 FRIEDRICH, G. (ed.). Codex diplomaticus et epistolaris regni Bohemiae II (1198-1230). Pragae: Sumptibus comitiorum regni Bohemiae, 1912, s. 412-415, č. 376, dále jen „CDB II““.

17 Historica relatio de conditoribus primo arcis dein Monasterii Gradicensis .... MZA Brno. E 55 - Premonstráti Klášterní Hradisko, sg. II 1, fol. 59r-60r. Více o prameni a jeho autorovi OPPELTOVÁ, J. Narativní prameny vzniklé v prostředí premonstrátské kanonie Klášterní Hradisko v Olomouci v 17. a 18. století. In: MACKOVÁ, M. - OPPELTOVÁ, J. (eds.). Slavme chvíli ... Sborník k 70. narozeninám Jana Bistrického. Ústí nad Orlicí: Státní okresní archiv, 1999 s. 83-121, zde s. 84-86, 114-115 v pozn.; TEIGE, c. d., s. 13 a násl.

18 HRABĚTOVÁ, $c$. d., s. 46 a 145 v pozn.; ELBEL, $c$. d., s. 41 v pozn.

19 Liber monasterii Gradicensis ... Klášterní archiv v Csorne, bez signatury, pag. 19-20. Popis a rozbor archiválie podle originálu podává ŠVOMOVÁ, P. Liber monasterii Gradicensis klášterního archivu Csorna (Edice listin z let 1283-1310) (Bakalářská práce FF MU). Brno, 2013; TÁŽ. Textová tradice diplomatických pramenů pro klášter Hradisko u Olomouce do r. 1310 (Diplomová práce FF MU). Brno, 2016. HRABĚTOVÁ, $c$. d., s. 46 a násl. měla v ruce pouze fotokopii.

20 BOČEK, A. (ed.). Codex diplomaticus et epistolaris Moraviae II (1200-1240). Olomoucii: Skarniztl, 1839, s. 77-80, č. LXVII.

21 ERBEN, K. J. (ed.). Regesta diplomatica nec non epistolaria Bohemiae et Moraviae I (600-1253). Pragae: Theophili Haase, 1855, s. 264-264, č. 562.

$22 \quad C D B I I$, s. $412-415$, č. 376.

23 ŠVOMOVÁ, Textová tradice, s. 30, č. $16^{+}$.

24 ELBEL, c. d., s. 43; HRUBÝ, Severni Morava, s. 9-10. 
na vrub neznámého autora, jenž v minulosti zasáhl do Siebenaicherova opusu. Rovněž Bočkovo a Erbenovo čtení postrádá opodstatnění. Vezmeme-li do úvahy dříve neznámý rukopis z Csorne, padá eventualita, že by hledaným rokem byl rok 1215. Zato vybrat mezi lety 1220 a 1205 si žádá rozvinutější argumentaci. Obě varianty se dají uvést do souladu s itinerářem moravského markrabího Vladislava Jindřicha, který je prohlašován za původce listiny. Současně je ale nutno přiznat, že Vladislavův životopis není prost bílých míst. ${ }^{25}$ Nejstaršímu hradišt'skému kopiáři chybí pevný systém, jelikož jeho uspořadatel kolísal mezi zřeteli věcnými a chronologickými. Proto nelze zjistit nic ani ze zařazení naší písemnosti v seznamu, v němž předchází listina z roku 1238 na Polom a následuje jiná na Domašov z roku 1269. Klíčem k řešení by však mohla být postava hradišt'ského opata Bonifáce, o jehož aktivitách se dozvídáme z CDB II 376. Jestliže opisu z Csorne předcházelo skutečné privilegium, ze kterého bylo přejato Bonifácovo jméno, stává se letopočet 1205 neudržitelným. Přinejmenším od roku 1201 až do roku 1213 zastával totiž v Hradišti opatský úřad Heřman a teprve po něm byl zvolen do čela Bonifác. ${ }^{26}$

Napovědět může i pozdní klášterní tradice. V inventáři hradišt'ských privilegií, který byl pořízen během 17. a 18. století a který pojal 39 kusů písemností od roku 1078 do roku 1471, se setkáváme u domašovské listiny s datem 1220 (Ao. 1220 Wladislaus m. M. per sententiam et per privilegium monasterio Grad. addicit quandam silvam inter Laszian et Domaschow). ${ }^{27}$ Stejný údaj byl k vidění v Siebenaicherových hradišt'ských análech předtím, než byl omylem revidován na 1225 . Na mysl tudíž přichází domněnka, že týž písař, který přenesl domašovskou listinu do kopiáře z Csorne (ruka A dle Hrabětové), si po vykonání díla uvědomil svou chybu a zpětně upravil datační formuli. Na okraj jednoduše poznačil „XX“, aby dostal náležitý rok 1220, zanesený v předloze. Zdá se ale, že korekturu nedokončil. $\mathrm{Z}$ nepozornosti, nebo z jiné pohnutky, o které můžeme akorát spekulovat, ponechal o řádek níže číslovku „Vo“, jež znesnadňuje stanovení dne v kalendáři, kdy měla být listina na domašovský les vydána. Je-li kombinace správná, samozřejmě s vědomím, že jde více o hypotézu, než o exaktně ověritelný fakt, vychází nám rok 1220 (anno domini $\left.M^{\circ} C C^{\circ} X X\right)$ a den 10. září (IIII ${ }^{\circ}$ idus septembris).

Nemenší úskalí je skryto v otázce, kdy vznikla a jaký charakter měla písemnost „zachráněná“ v 15. století hradišt'ským kopistou, od nějž v 17. století opisoval páter Siebenaicher. V literatuře panuje shoda, že se jednalo o falzum, protože některé jeho pasáže jsou doslovnou kompilací z listin bud' pravých, nebo podezřelých, uložených v klášterním archivu v Hradišti, sepsaných ale každopádně po roce $1220 .{ }^{28}$ Souhlasně se také přijímá, v návaznosti na př́íspěvek Jiřího Paclíka vzešlý z brněnského Šebánkova semináře, že podvržený dokument byl zhotoven na jméno markrabího Vladislava Jindřicha v kanceláři

25 WIHODA, M. Vladislav Jindřich. 2. přepracované vydání. Praha: Argo, 2019, s. 227 a nás1.; TÝŽ. Itinerář moravského markraběte Vladislava Jindřicha. Sborník praci Filozofické fakulty brněnské univerzity. Řada historická (C), 2000, roč. 49, č. 47, s. 5-45.

26 BACKMUND, N. (ed.). Monasticon Praemonstratense I-1. Editio secunda. Berlin - New York: De Gruyter, 1983, s. 357. Na druhou stranu, pokud bychom měli písemnost za úplně smyšlenou, což se zdá s ohledem na její věcnou přesnost méně pravděpodobné, dala by se připustit i možnost, že falzátor z Hradiště chyboval dokonce v osobních datech opatů. Jeho neznalostem nastavují zrcadlo spuria $C D B$ II, č. 351, s. 363 a $C D B I I$, č. 352, s. 365, která jsou témuž autorovi připisována. Ačkoliv nesou datum 1200, resp. 1201, jsou adresována abbati Bonifacio.

27 Cituje TEIGE, $c$. d., s. 40. Srv. HRABĚTOVÁ, $c$. d., s. 84 v pozn.

28 Viz poznámky editora k CDB II, s. 412-415, č. 376. 
př́ijemce, kterým byla premonstrátská kanonie Hradiště u Olomouce. ${ }^{29}$ Názory medievistů se naopak rozcházejí, mají-li upřesnit časový horizont, kdy k padělání došlo. Pokud není po ruce originál, nelze pomýšlet na paleografický rozbor a nezbývá, než se zaměřit na sloh listiny, jehož analýza ovšem nemusí dospět k jednoznačným závěrům. ${ }^{30}$ Zatímco Gustav Friedrich se u CDB II 376 dopátral stylistických paralel s dvěma listinami psanými dle Friedricha rukou počátku 14. století a u všech tří předpokládal společného autora, ${ }^{31}$ Jiří Paclík se diplomatickou metodou dopracoval k diktátorovi působícímu v Hradišti v rozmezí let 1272-1289, o němž Paclík soudí, že měl na svědomí celou řádku fals včetně toho domašovského, sestaveného někdy v 80. letech 13. století. ${ }^{32}$ Prokop Zaoral, který se po Friedrichovi zaobíral kanceláŕí Vladislava Jindřicha, zase na podobné snahy zcela rezignoval a navíc konstatoval, že ,prokazatelný vliv pravých listin se dá těžko poznat““.33 Musíme se tedy spokojit s odhadem, dodaným od specialistů v oboru pomocných věd historických, že listina na Domašov spatřila poprvé světlo světa v klášteře Hradišti v rozmezí od 80 . let 13. století do doby kolem začátku 14 . století.

Samotný fakt, že máme co do činění s padělkem, ale neznamená, že by musela být a limine zavrhnuta obsahová náplň listiny a zpochybněna její autenticita. ${ }^{34} \mathrm{U}$ odborné veřejnosti se můžeme setkat vesměs se vstřícnějším přístupem $\mathrm{k}$ hradišt'skému skriptoriu. S takovým, který bere v potaz, nakolik podvrhy klášterní provenience vskutku korespondují s dobou, do níž se hlásí. O pravdivém jádru v CDB II 376 byl ochoten svého času uvažovat Václav Štěpán, který hájil faktografickou spolehlivost dalšího hradišt'ského falza, nesoucího datum 1269, jehož tenorem byly opět majetkové hranice na Domašovsku. ${ }^{35}$ Nejinak Martin Wihoda, který se vyslovil, že podvržený dokument mohl citovat ztracené privilegium Vladislava Jindřicha a že „odpovídá správě věcí veřejných v prvních dvou dekádách 13. století‘. ${ }^{36} \mathrm{~V}$ hodnocení se neliší ani Dalibor Janiš, podle jehož názoru text „poskytuje řadu pozoruhodných informací o průběhu soudního zasedání, jeho formulace

29 PACLÍK, c. d., s. 18 a násl.

30 Pro ilustraci lze prolistovat ZAORAL, P. O listinách a kanceláři markraběte moravského Vladislava Jindřicha. Sborník Matice moravské, 1967, roč. 86, č. 1, s. 219-230.

31 Viz poznámky editora k CDB II, s. 362-364, č. 351; CDB II, s. 364-368, č. 352; CDB II, s. 412-415, č. 376. Ve starší práci pomýšlel ještě na konec 13. stol. FRIEDRICH, G. O kanceláŕi a listinách markrabi moravských Vladislava a Přemysla (1198-1239). Přispěvek k české diplomatice. V Praze: Nákladem Královské České Společnosti Nauk v kommissi u Fr. Řivnáče, 1896, s. 42.

32 PACLÍK, c. d., s. 21 a násl., $86 \mathrm{v}$ pozn.

33 ZAORAL, c. d., s. 222 v pozn.

34 Srv. KREJČÍKOVÁ, J. Diplomatická činnost v českém státě v letech interregna. Sborník prací Filozofické fakulty brněnské univerzity. Řada historická (C), 1989-1990, roč. 38-39, č. C36-37, s. 147-164, zde s. 153 a 160 v pozn. V širším kontextu a s bibliografí ŠRÁMEK, J. „Aby události neunikly paměti“. Středověká listinná falza a kláštery. Acta historica Universitatis Silesianae Opaviensis, 2009, roč. 2, s. 13-37. K metodickým východiskům DUŠKOVÁ, S. Zur Problematik der vermeintlich aus dem 13. Jahrhundert stammenden Urkundenfälschungen in den böhmischen Ländern. Archivmitteilungen, 1991, Jhrg. 41, Heft 4, s. 179-185, zvl. s. 183 a násl.

35 ŠTĚPÁN, V. Listina hradišt'ského kláštera údajně z roku 1269. Z dějin hutnictví, 1986, sv. 15, s. 18-41, zde s. 20 a 31-32 v pozn. je polemikou s Paclíkem.

36 WIHODA, M. Klášter Panny Marie a svatého Jiří ze Střelné. Pokus o návrat k jednomu již spatřenému. In: DOLEŽALOVÁ, E. - MEDUNA, P. (eds.). Co můj kostel dnes má, nemůže kniže odníti. Věnováno Petru Sommerovi k životnímu jubileu. Praha: NLN, 2011, s. 138-144, zde s. 139. Podobně TÝŽ, Vladislav Jindřich, s. 169. 
ale byly ovlivněny pozdějšími písemnostmi“.37 Oba výroky poté souzní s představami Petra Elbela, ${ }^{38}$ Jiřího Doležela, ${ }^{39}$ Pavla Šlezára a Pavla Boliny, ${ }^{40}$ kteří po vzoru Františka Hrubého ${ }^{41}$ kalkulují s možností, že se kancelář premonstrátů v Hradišti opírala při vyhotovování padělků o starší, dávno zmizelou či zničenou dokumentaci. ${ }^{42}$

Chceme-li se ujistit o historické ceně domašovské listiny, můžeme navázat na postřehy, které snesl při studiu hradišt'ské diplomatiky Václav Štěpán. ${ }^{43}$ Ve světle jeho myšlenkových pochodů se nejvhodnějším metodologickým prostředkem jeví být právněhistorická mikrosonda doprovázená srovnáním s ostatními listinnými prameny z doby přemyslovské. Cílem je ověřit, do jaké míry se dá zakomponovat CDB II 376 do celkového obrazu o právním životě českého a moravského středověku. Pobídkou do diskuze je proto skeptický hlas Jiřího Paclíka, který tvrdí, že falzum na domašovský les nebylo než prostou fabulací, jež měla vylepšit pozici kláštera v majetkoprávním sporu se Šternberky. ${ }^{44}$ Ve všeobecnosti můžeme ale přeci namítnout, že tvořivost středověkých falzátorů byla určitým, byt’ v pramenech ne vždy postihnutelným způsobem limitována, nebot' podléhala soudcovskému hodnocení důkazů. Z málomluvného diplomatického materiálu lze vyčíst, že až do husitských válek nebyla listina jediným a zpravidla ani nejdůležitějším důkazním prostředkem na zemských soudech. ${ }^{45}$

Totéž platilo i pro soudní, anebo smírčí řízení o nemovitý majetek a jeho meze. Písemnost, at' pravá či zfalšovaná, jíž se účastník dovolával na podporu svého tvrzení, mohla být konfrontována se svědeckou výpovědí, vyžadovanou jak soudci, tak rozhodci. ${ }^{46}$ Pro prŕíklady nemusíme chodit daleko. Ve vleklých tahanicích o pozemky, které vyplňovaly druhou polovici 13. století a které sváděli opati Robert a Budiš z premonstrátské kanonie v Hradišti se svými sousedy, mívali hlavní slovo právě svědkové. Roku 1255 se před olomouckým

Že falza zpravidla nevznikala „z ničeho“ a že mohou být cenným dokladem o minulosti, demonstruje názorně DUŠKOVÁ, S. Fälschungen böhmischer Königsurkunden im 13. Jahrhundert. In: Fälschungen im Mittelalter. Internationaler Kongreß der Monumenta Germaniae Historica München, 16.-19. September 1986. Teil IV. Hannover: Hahn, s. 597-615.

43 ŠTĚPÁN, $c$. $d$.

44 PACLíK, c. d., s. 59-60, a před ním již PINKAVA, c. d., s. 395-396.

45 KEJŘ, J. Die Urkunde als Beweismittel im Gerichtsverfahren im mittelalterlichen Böhmen. In: ADAMSKA, A. - MOSTERT, M. (eds.). The Development of literate mentalities in east central Europe. Turnhout: Brepols, 2004, s. 51-58, zde s. 55-56. V širším záběru HÄRTEL, R. Urkundengebrauch und Zeugenbeweis im Hochmittelalter. Archiv für Diplomatik, 2019, Bd. 65, s. 15-45, zde zvl. s. 21 a násl.; JUREK, T. Die Rechtskraft von Urkunden im mittelalterlichen Polen. In: ADAMSKA - MOSTERT, c. d., s. 59-91, zde zvl. s. 81-82, 85-86; VAN CAENEGEM, R. Ch. La Preuve dans le droit du Moyen Âge occidental Rapport de Synthèse. In: La preuve 2. Moyen âge et temps modernes. Bruxelles: Ed. de la Libr. Encyclopedique, 1965, s. 691-754, zde s. 744-745.

46 Srv. JIREČEK, H. Über Eigenthumsverletzungen und deren Rechtsfolgen nach dem altbömischen Rechte. Ein Beitrag zur Geschichte des Rechtes in Österreich. Wien: Druck der Mechitharisten-Buchdruckerei, 1855, s. 32-33, který čerpá z mladších normativních pramenů. 
soudním fórem probíralo vlastnictví lesní plochy, která ležela mezi Knínicemi a hranicemi vsi Střelechy. Nárok na půdu si dělali mniši z Hradiště a několik usedlíků, patrně drobných šlechticů z přilehlých Vážan. Po vyslechnutí sedmi urozených mužů, z nichž tři př́isahali na svaté ostatky, byl pak les přiřčen klášteru (produxi nobiles viros ... qui interrogati super fidem catholicam et in animam suam protestati sunt). ${ }^{47}$ Roku 1278 panovníkem delegovaní soudci na zasedání v Brně rozhodli v neprospěch jistého Parduse, který se s hradišt'skými premonstráty dohadoval o statky na Olomoucku, darované církvi Pardusovým otcem Neplachem, avšak ztroskotal, protože nedokázal své právo obhájit svědectvím tř́ hodnověrných beneficiářů (per tres testes ... intencionem suam probare non potuit). ${ }^{48}$

Na sklonku roku 1279 se před soud dostala rozepře mezi Budišem a Albertem z Lešan, točící se kolem výměry klášterních držav mezi vesnicemi Knínice a Konice. Není přitom bez zajímavosti, že ačkoliv opat předložil listiny a Albert proti nim neprotestoval (manifeste per sue privilegia ecclesie inibi declaravit eisdem privilegiis adversa parte contradicere non valente), olomoucký biskup Bruno ve funkci sudího se k dokumentům stavěl rezervovaně, snad že mu byly podezřelé. Konečný verdikt naklonila na stranu premonstrátů až výpověd’ královského vilika Jana, dobře zpraveného o hraničních poměrech (personam, cui constaret de facto). ${ }^{49} \mathrm{Na}$ soudním shromáždění v Olomouci byla potom ještě roku 1286 uzavřena letitá kauza, jejímž předmětem byla ves Těšetice. O její část se přel hradišt'ský opat Budiš s dědičkami původního majitele Časty z Křelova. Protože si Budiš zajistil pomoc šlechticů, ochotných vydat svědectví pod přísahou (testes omnia, que testati fuerant, ante crucem constituti secundum ius terre, uera esse parati essent adstruere iuramento), byla protistrana donucena uznat jeho nárok a přistoupit na kompromis. ${ }^{50}$

Jakkoliv si hradišt'ští mniši ve vlastnických sporech vypomáhali listinami, museli být připraveni, že během přelíčení bude písemné svědectví posuzováno společně s ústními prohlášeními a že by tudíž neměl být mezi oběma průvody nepřekonatelný rozpor. Pravděpodobnost, že CDB II 376 popisovala realisticky jednak situaci na Domašovsku, jednak soudní a úřední peripetie spojené s právní ochranou církevního majetku, dále stoupá, uvědomíme-li si, jaký postoj k hradišt’ským dokumentům zaujali Šternberkové coby odpůrci kláštera. Když byl Albert ze Šternberka stižen těžkou chorobou, pořídil roku 1281 testament. Aby se zbavil klatby, vyhlášené olomouckým biskupem Brunem kvůli ško-

47 ŠEBÁNEK, J. - DUŠKOVÁ, S. (eds.). Codex diplomaticus et epistolaris Regni Bohemiae V-1 (1253-1266). Praha: Academia, 1974, s. 103-105. č. 50, dále jen „CDB V-1“. Srv. DOLEŽEL, c. d., s. 148-149; JANIŠ, Zemské soudnictví, s. 188-189.

48 ŠEBÁNEK, J. - DUŠKOVÁ, S. (eds.). Codex diplomaticus et epistolaris Regni Bohemiae V-2 (1267-1278). Praha: Academia, 1981, s. 576-578, č. 858, dále jen „CDB V-2“. Srv. JAN, L. Vznik zemského soudu a správa středověké Moravy. Brno: Masarykova univerzita a Matice moravská, 2000, s. 138-139 a v pozn.; JANIŠ, Zemské soudnictví, s. 193-194.

49 SVITÁK, Z. - KRMÍČKOVÁ, H. - KREJČÍKOVÁ, J. et al. (eds.). Codex diplomaticus et epistolaris Regni Bohemiae VI-1 (1278-1283). Praha: Academia, 2006, s. 127-131, č. 79+ a 80++, dále jen „CDB VI-1“. Srv. ŠTACHOVÁ, N. Ke sporu hradiského opata Budiše s Albertem z Lešan 26. 11. 1279. Úvaha o zemském právu v období tzv. prvního interregna. In: KNOLL, V. - KARHANOVÁ, M. (eds.). Naděje právni vědy. Býkov 2007. Plzeň: Aleš Čeněk, 2008, s. 174-179; DOLEŽEL, c. d., s. 150-152.

50 BOČEK, A. (ed.). Codex diplomaticus et epistolaris Moraviae. Tomus IV (1268-1293). Olomouc: Skarniztl, 1845, s. 312-313, č. CCXXXIX, dále jen „CDM IV“. Srv. HAVEL, D. (ed.). Katalog listin a listů k VII. dílu Českého diplomatáre I (Zpracováni diplomatického materiálu pro obdobi květen 1283 - květen 1297). Brno: Matice moravská pro Výzkumné středisko pro dějiny střední Evropy: prameny, země, kultura, 2011, s. 76-77, č. 182; JANIŠ, Zemské soudnictví, s. 198-199. K dataci JAN, Vznik zemského soudu, s. 142. 
dám páchaným na církevním zboží, zavázal se Albert př́isahou na kříž nahradit bezpráví, kterých se předtím dopustil na premonstrátech z Hradiště a na olomouckém biskupství. Pozoruhodné na Šternberkově poslední vůli ale především je, že rezignuje na neprávem zadržované klášterní statky a jedním dechem uznává platnost hradišt’ských privilegií (bona Gradicensis ecclesie, que occupaveram, dimitto libere dicte ecclesie possidendum secundum limites et terminos, qui in privilegiis ipsius ecclesie continentur). ${ }^{51}$

Než se budeme moci odhodlat a z perspektivy středověké právní kultury odvyprávět př́iběh, který máme plasticky zachycen ve falzu CDB II 376, bude nezbytné upozornit znova na složitou genezi hradišt'ské písemnosti, která je pestrou mozaikou poskládanou z většího množství diplomatických pramenů. Pokud bychom se měli pokusit identifikovat pravé jádro písemnosti, nabízí se již nadnesená hypotéza, že jím bylo soudní rozhodnutí. Vyneseno bylo na sjezdu moravské šlechty ve Znojmě a vyznívalo ve prospěch mnichů z Hradiště. Jeho leitmotivem byly lesní pozemky u Domašova nárokované premonstrátským klášterem. Můžeme se domýšlet, že vítězná strana si bez dlouhého otálení vyžádala konfirmaci od Vladislava Jindřicha, předsedajícího tehdy znojemskému soudu. Písemná památka, která je dnes nezvěstná, svým obsahem zřejmě nevybočovala ze sněmovní agendy 13. století a byly v ní zaneseny odjinud neznámé, avšak věrohodně podané okolnosti procesu. Nicméně později už soudní listina nepostačovala, a proto ji hradišstský falzátor přizpůsobil novým požadavkům své instituce. Nevysloveným záměrem, za nímž stálo letité soupeření mnichů z Hradiště s okolními pozemkovými vlastníky, mohlo být dokonalejší právní zajištění klášterního velkostatku. Nesmíme totiž zapomínat, že těžiště sporu leželo v dynamicky se rozvíjející kolonizační oblasti, která přitahovala zájem vrchností světských i duchovních. ${ }^{52}$

Jak konkrétně si v písařské dílně v Hradišti počínali, zůstává pouhým dohadem. Přesto máme spolehlivé indicie, že padělatelé drželi v ruce listiny schraňované v archivu, který býval ve středověku přičleněn ke kostelnímu pokladu a který v Klášterním Hradišti vykazuje od 13. století známky soustředěnější organizační činnosti (indorzáty). ${ }^{53}$ Není vyloučeno, že původní dokument z roku 1220 byl přepsán a doplněn o nějaký zápis, vypočítávající „krok za krokem“ hraniční ukazatele v lesem pokrytém terénu, který na Domašovsku zavdával prŕíčiny k neshodám. ${ }^{54}$ Jiným zdrojem, rovněž snad pojatým do falza, aby se zvýšila jeho užitná hodnota, mohla být listina či pamětní záznam o úřední obchůzce, vykonané okolo domašovského lesa. Rozumí se samo sebou, že právní rituál nemohl přijít na řadu dříve, než bylo soudně deklarováno, že se objekt nachází ve vlastnictví kláštera. Z potvrzení, které bylo po skončení ochozu pořízeno, dala se převzít zmínka o rituálních

$51 \quad C D B V I-1$, s. 173-175, č. 127. Srv. POKLUDA, Z. Moravští Šternberkové. Panský rod rozprostřený od Jeseniků ke Karpatiom. Praha: NLN, 2012, s. 62.

52 O trendu 13. století k upevňování majetkových práv jejich přesnějším vymezením v listinách ŽEMLIČKA, J. Království v pohybu. Kolonizace, města a střibro v závěru přemyslovské epochy. Praha: NLN, 2014, s. 294 a násl.

53 ŠVÁBENSKÝ, c. d., s. 15-16.

54 Proti dřívějšímu stanovisku Friedrichovu a Pinkavovu bylo poukázáno, že podrobná charakteristika průběhu hraniční čáry, jakou zde nacházíme, není výjimečným zjevem mezi nepodezřelými listinami z první poloviny 13. století. Srv. HRUBÝ, V. Tři studie k české diplomatice. Brno: Filosofická fakulta s podporou Ministerstva školství a národní osvěty v komisi knihkupectví A. Píša v Brně, 1936, s. 43 a v pozn. 241, s. 62 a v pozn. 489; ŠTĚPÁN, c. d., s. 21, 32 v pozn. Že „kruhové“ popisy hranic byly typické pro hradišt'ské prostředí a že skýtaly oporu pro zdejší falzátory, konstatují BOLINA - ŠLEZÁR, c. d., s. 312 a v pozn. 
praktikách při nakládání s nemovitostmi a personálie hradských úředníků z Olomoucka, o kterých CDB II 376 zasvěceně informuje. ${ }^{55}$

Od rekonstrukce písemnosti, sestavené ve zdech klášterního skriptoria v Hradišti, odvíjejí se také možnosti, které máme, chceme-li vyzdvihnout zlomové události konfliktu o domašovský les a objasnit jejich chronologii. Půjdeme-li popořadě, soudci zasedli k rokování ve Znojmě nejspíše 10. září 1220, kdy je CDB II 376 datováno. Lze vycházet z předpokladu, že formule Actum et datum in Znoim odkazuje na nejdůležitější právní jednání (actum), které se hned nato stalo předmětem zlistinění (datum). Těžko lze tady myslet na něco jiného, než na přenesení sporné záležitosti před zemské právní fórum a na meritorní rozsudek, zaštit’ující se autoritou zeměpána. ${ }^{56}$ Obejití klášterních pozemků se uskutečnilo daleko od místa sudiště, u Domašova na Olomoucku, a jelikož navazovalo na soudní řízení, lze jej odsunout někam za záŕijové datum, které máme v listině uvedeno. Pakliže soud či arbitráž probíhaly v blízkosti nemovitosti, jejímž právním osudem se zabývaly, mohl se časový odstup mezi vydáním rozhodnutí a úředním vytyčením hranice pohybovat v horizontu dní. ${ }^{57}$ Analyzovaný př́ípad je však odlišný a s přihlédnutím $\mathrm{k}$ cestovní vzdálenosti je nutno počítat se lhůtou podstatně delší. ${ }^{58}$

\section{Před zemským soudem ve Znojmě}

Po celkovém zhodnocení pramenné základny se nyní můžeme na neklidnou historii domašovských statků zaměřit detailněji. Zopakujme, že dějová linka postřehnutelná v CDB II 376 se začala odvíjet na podzim roku 1220, kdy zasedl ve Znojmě soudní tribunál pod

55 Prameny toho druhu známe z 13. století jednak jako listiny znějící na jméno úředníků, kteří se ujali ohraničování pozemků: $C D B V-2$, s. 479-481, č. 795+'; Archiv Národního muzea, Pergamenové listiny, sg. A 37 = HAVEL, D. (ed.). Katalog listin a listů, s. 124, č. 323; IRGANG, W. - SCHADEWALDT, D. (eds.). Schlesisches Urkundenbuch VI (1291-1300). Köln: Böhlau, 1998, s. 147-148, č. 184, dále jen „SUb VI“; CHYTIL, J. (ed.). Codex diplomaticus et epistolaris Moraviae V (1294-1306). Brunae: C. Winiker, 1850, s. 105-106, č. CIII, dále jen „CDM V“. Jednak jsou dochovány ve formě pamětních zápisů, opatrovaných církevními nabyvateli: EMLER, J. (ed.). Regesta diplomatica nec non epistolaria Bohemiae et Moraviae II (1253-1310). Pragae: Typis Grégerianis, 1882, s. 717-719, č. 1673 a 1674, s. 725, č. 1687, dále jen „RBM II“; PATERA, A. (ed.). Píseň staročeská ze XIII. století: „Slovo do světa stvořenie“. Časopis Musea království Českého, 1878, roč. 52, č. 2, s. 289-294, zde s. 290 = HAVEL, D. (ed.). Katalog listin a listů, s. 355-356, č. 913. Blíže PRAŽÁK, J. Rozšíření aktů v přemyslovských Čechách: k počátkům české listiny. In: MALÝ, K. (ed.). Collectanea opusculorum ad iuris historiam spectantium Venceslao Vaněček septuagenario ab amicis discipulisque oblata. Pocta akademiku Václavu Vanéčkovi k 70. narozeninám. Praha: Universita Karlova, 1975, s. 29-40, zde s. 33; BLÁHOVÁ, M. Pamětní zápisy (akty) v českých zemích od konce 10. do konce 13. století. Historia Slavorum Occidentis, 2012, Tom 1 (2), s. 72-84, zde s. 81. Ve všech př́padech se jedná o výčty beneficiářů a ostatních významnějších svědků, jejichž jména jsou zarámována do někdy obšírnější, někdy stručnější zprávy o mezním rituálu a eventuálně i o jeho právním důvodu.

56 Srv. ŠTĚPÁN, $c$. $d$., s. 28.

$57 \quad C D B V-1$, s. 569-570, č. 384; $C D B V-2$, s. 479-481, č. $795^{+}$.

58 RBM II, s. 605-606, č. 1409; Archiv Národního muzea, Pergamenové listiny, sg. A 37 = HAVEL, D. (ed.). Katalog listin a listů, s. 124, č. 323. Zde se dočteme o cca půlroční prodlevě, která nastala mezi prodejem dvou vesnic prohlášeným na zemském soudě v Praze (13. 5. 1287) a komisionálním ohraničením majetků na Žatecku, u nějž lze z neúplné datovací formule Acta sunt hec anno domini $M^{\circ} C^{\circ} C^{\circ} L X X X^{\circ} V I I$ in die sancti Th... martiris získat asi nejspíše svátek Sv. Teodora mučedníka (9. 11. 1287). Blíže FIEDLEROVÁ, N. - RAZIM, J. Representing Rituals in medieval Bohemia: Circuitio in the Documents of the Late 13th Century. Studia historica Brunensia, 2018, roč. 65, č. 1, s. 63-77. 
patronátem moravského markraběte Vladislava Jindřicha. ${ }^{59}$ Verdikt, ke kterému přísedící dospěli, přiřkl hradišt'skému klášteru les, rozprostírající se u vesnic Lašt’an a Domašova, jehož pohostinnosti zneuživali obyvatelé z přilehlé vsi Lužice. Stojí za pozornost, že v roli odpůrců vystupují Lužičtí, kteří jsou označováni jako lidé markraběnky, Vladislavovy choti, což naznačuje jejich někdejší zeměpanskou př́íslušnost. Ve 13. století byl ale zdejší prostor osídlován rodem Šternberků a v době padělání naší listiny byla již Lužice pevně vtělena do šternberského panství na úpatí Nízkého Jeseníku. V rodu s erbem hvězdy tak vyrostl Hradišti protivník, jenž klášterní hospodaření přímo ohrožoval a nutil mnichy k „,výrobě“ důkazů. ${ }^{60}$ Naznačený směr argumentace podporuje jiné hradišs’ské falzum z přelomu 13. a 14. století, spočívající s velkou dávkou pravděpodobnosti na dobových reáliích. Podle něj domašovské církevní statky v druhé polovině 13. věku čelily tlakům Alberta ze Šternberka a jeho bratrů, se kterými se premonstráti snažili v roce 1269 prostřednictvím delegovaných královských rozhodců usmírit a byli za tím účelem ochotni $\mathrm{k}$ nemalým teritoriálním ústupkům. ${ }^{61}$

V eskalujícím majetkoprávním sporu (orte lita) mezi klášterem a lidmi z Lužice se obě strany přetahovaly o zalesněné, mezníky obehnané území (silva) poblíže Domašova u Šternberka, jehož součástí byla jednak naleziště železné rudy a stavebního materiálu (montibus, ubi metallum ferri foditur, et aliis montibus, in quibus molares lapides acquiruntur), jednak krajinou tekoucí potoky s rýžovišti zlata (rivulis, in quibus aurum foditur). ${ }^{62}$ Zatímco o těžbě drahých kovů se mezi odborníky pochybuje, že by se v okolí Domašova soustavněji provozovala, dobývání a zpracování železa se ve světle hradišt'ských listin jeví být nejen vítanou položkou na seznamu vrchnostenských prř́jmů, ale i přirozenou roznětkou nepřátelství mezi premonstrátskou kanonií a Šternberky. ${ }^{63}$ Poněvadž

59 Zběžnou rekapitulaci s vročením 1215 mají např. DUDÍK, B. Dějiny Moravy IX. Kulturní poměry na Moravě od roku 1197 do 1306 (Stát a národství). V Praze: Nákladem B. Tempského, 1884, s. 45-46, 77; ŠUJAN, F. Nejstarši zřizení zemské na Moravě. 2. vydání. Brno: nákl. vl., 1926, s. 47-48.

60 Shodně BOLINA, P. Pokus o modelové řešení některých problémů kolonizace a vzniku hradů v Nízkém Jeseníku. Archaeologia historica, 2002, roč. 27, s. 163-178, zde s. 166-167, a před ním HRUBÝ, Severní Morava, s. 62-65.

$61 \quad C D B V-2$, s. 193-195, č. 599++. Rozbor podává ŠTĚPÁN, c. d. V historickém kontextu WIHODA, Vladislav Jindřich, s. 168 a násl.; POKLUDA, Moravšti Šternberkové, s. 38-39, 62; HRUBÝ, Severní Morava, s. 48 a násl.

62 K interpretaci molares lapides jakožto sedimentární horniny zv. droba, vhodné k výrobě mlýnských kamenů, BAKALA, J. Počátky těžby kovů v Nízkém Jeseníku a vznik Horního Benešova. In: TÝŽ. Moravskoslezské pomezí v proménách 13. věku. Výbor z článků a studií. Brno: Matice moravská, 2002, s. 347-372, zde s. $368 \mathrm{v}$ pozn.

63 Nerostnému bohatství v této oblasti se věnoval BERGER, K. Die Besiedlung des deutschen Nordmährens im 13. und 14. Jahrhunderte. Brünn: Deutscher Volksschulverband in Mähren, 1933, s. 249 a násl. Stručněji ŠTĚPÁN, c. d., s. 22-24; KOŘAN, J. Přehledné dějiny československého hornictví 1. Praha: Nakladatelství Československé akademie věd, 1955, s. 109; CHARVÁT, P. Zpracování železa v písemných pramenech českého stř̌edověku do počátku 14. století (s přihlédnutím k výzkumu v Chýnici). Archeologické rozhledy, 1985, roč. 37, č. 2, 181-185, zde s. 183; MERTA, J. Zásobování města Brna železem v období stř̌edověku. In: MĚŘÍNSKÝ, Z. (ed.). Forum Urbes Medii Aevi 6. Surovinová základna a jeji využití ve středověkém městě. Brno: Archaia, 2011, s. 184-193, zde s. 187-188. Kladně pro možnost dolování zlata NOVÁK, J. K vývoji dolování drahých a barevných kovů na severní Moravě. Zprávy Krajského vlastivědného muzea v Olomouci, 1979, č. 201, s. 1-9, zde s. 2. Skeptičtěji NOVÁK, J. - ŠTĚPÁN, V. Báňsko-historický výzkum Hrubého Jeseniku a západní ćásti Nizkého Jeseníku ložisek drahých a barevných kovi̊. 4. Ložisková oblast Ag-Pb-Cu rud v povodi ř ky Bystřice-Lošov, Velká Bystřice, Hlubočky, Hrubá Voda. Praha: Ústřední Ústav geologický, 1984, s. 13. Strojopis zprávy je uložen v Archivu Geofondu při České geologické službě pod 
se les podle novějších zjištění Petra Elbela nenacházel v majetku kláštera při jeho založení v letech 1077-1078, musel do jeho pozemkového fondu přibýt jindy. ${ }^{64}$ Snad za panování Vladislava Jindřicha, k čemuž se kloní František Hrubý, nejpozději ale před rokem 1220, kdy se vlastnické poměry v této části Nízkého Jeseníku dostaly na pořad znojemských jednání. ${ }^{65}$

Starý český a moravský proces byl ovládán zásadou akuzační, podle níž se rrízení zahajovalo na kvalifikovaný podnět z vnějšku. Hradišs'ské mnichy zastupoval opat Bonifác, jenž stanul v čele komunity po smrti svého předchůdce opata Heřmana. Ve kterém roce se chopil funkce, zůstává však obestřeno tajemstvím. Bezpečně je jeho pobyt v Hradišti prokázán až od roku 1221. ${ }^{66}$ Aby svým nárokům dodal váhu a aby je dokázal účinně prosadit proti rušitelům církevního zboží, musel Bonifác pohnat Lužické před zemský soud. Nedozvídáme se nic o okolnostech doručování půhonu, tedy o soukromém předvolání a pobídce žalovanému, aby spolupůsobil ve vedení pře. Není ostatně divu, ani soudobé prameny nejsou sdělnější. ${ }^{67}$ Známe nicméně výsledek přípravného rrízení. Bonifácova stížnost se řešila na shromáždění moravských předáků, které ve 13. století plnilo úlohu sudiště i politického fóra (curiam nostram sive colloquium nobis cum nostris baronibus ... celebrantibus). ${ }^{68}$ Rokování se odbývalo ve Znojmě (in Znoim), v tradičním správním centru na jižní Moravě. Přesnější lokalizaci bohužel postrádáme, k mání je pouze listinný údaj potvrzující, že když do Znojma roku 1279 soudcové opět zavítali a za cíl si dali smírně ukončit jeden pozůstalostní spor, jejich jednání probíhalo ve městě. ${ }^{69} \mathrm{~S}$ jistotou lze alespoň říci, že roku 1220 se kdesi ve Znojmě sešla mocenská elita nejen místní, ale ze všech koutů země, ${ }^{70}$ aby za předsednictví markraběte Vladislava Jindřicha vyslechla sváŕící se strany, které sem byly ve věci domašovského lesa předvolány (partibus convocatis in nostra praesentia constitutis).

Řízením jednání byl pověřen olomoucký sudí Velíz (Veliz iudici), profesionální znalec práva, doložený ve funkci ještě v letech $1222-1225 .{ }^{71}$ Kdo spolurozhodoval o sporu, není jasno, víme ale, že znojemské osazenstvo tvořilo vrcholek politické a společenské hierarchie (baronum, baronibus). Listiny doby přemyslovské jsou skoupé na biografická data

sg. P049324. K všestranným možnostem exploatace lesa ve středověku VELÍMSKÝ, T. Trans montes, ad fontes! (přes hory, k pramenům!). K roli újezdi̊ při středověké kolonizaci střednich a vyššich poloh na území severozápadních Čech. Most: Ústav archeologické památkové péče severozápadních Čech, 1998, s. $108-110$.

64 ELBEL, c. d., s. 44 v pozn., 54-55.

65 HRUBÝ, Severní Morava, s. 7 a násl. Dále srv. HOSÁK, L. Středověká kolonisace v oblasti Jeseníků. Časopis Společnosti přátel starožitností, 1955, roč. 63, č. 2, s. 65-78, zde s. 72 a násl.

66 HOSÁK, Historický místopis, s. 27; BACKMUND, N. (ed.). Monasticon Praemonstratense I. Editio prima. Straubing: Cl. Attenkofersche Buchdruckerei, 1949, s. 293. Zdrženlivější je ve svých odhadech novější vydání BACKMUND, Monasticon Praemonstratense I-1. Editio secunda, s. 357.

67 MARKOV, J. Připravné řizení procesní v českém právu zemském XIII.-XVII. stol. Bratislava: Právnická fakulta university Komenského, 1930, s. 39-41.

68 JAN, Vznik zemského soudu, s. 146-147; JANIŠ, Zemské soudnictví, s. 185-186, 205 s další literaturou.

69 CDB VI-1, s. 95-97, č. 51. Srv. JAN, Vznik zemského soudu, s. 140; JANIŠ, Zemské soudnictví, s. 205. Více ŠTACHOVÁ, N. Šlechtické testamenty v listinné praxi českých zemí do roku 1306. Časopis pro právní vědu a praxi, 2012, č. 3, s. 245-256, zde s. 250-251.

70 K proměnlivému formátu shromáždění JAN, Vznik zemského soudu, s. 145; JANIŠ, Zemské soudnictví, s. 203-204.

71 JAN, Vznik zemského soudu, s. 82. 
o přísedících a spokojují se obvykle paušálním tvrzením o přítomnosti úředních osob. ${ }^{72}$ U hradišt'ského falza je stav podobný, jistým překvapením naopak je, že mezi svědky nenarazíme na zástupce ze Znojma, kde se soud konal. ${ }^{73}$ Při bližším zkoumání jejich totožnosti se ovšem pramenná kritika střetává s dvěma problémy. Zaprvé, že svědečná formule je prríliš vágní (Huius rei testes sunt), než aby se dalo určit, k jakému časovému okamžiku se vztahuje. ${ }^{74}$ Zadruhé, že dikce neodpovídá době, do níž se písemnost hlásí. Výpovědní hodnotu snižují druhotné zásahy falzátora do původního textu, které se prozrazují ve stylistických paralelách s konfirmací Vladislava Jindřicha pro premonstráty z Hradišše, datované rokem 1200 a týkající se trhové vsi Knínice. ${ }^{75}$ Ve svědečné řadě jsou proto zaznačena konkrétní jména pouze u úředníků z Olomoucka, v jejichž obvodu se premonstrátský klášter majetkově angažoval. Jde o komorníka Bavora, kastelána Záviše a dříve zmíněného sudího Velíze (Bavarus camerarius, Zavissie castellanus, Veliz iudex, Olomucenses beneficiarii, et alii plures fide digni).

Úvod přelíčení obstaral představený kláštera Hradiště, když osobně přednesl žalobu (petivit abbas) domáhaje se, aby bylo ,učiněno spravedlnosti zadost“" (fieri iustitiae complementum) ${ }^{76} \mathrm{Z}$ právních kroků, které následovaly, vysvítá, že i v naší kauze můžeme počítat $\mathrm{s}$ uplatněním některých obecnějších pravidel, jež ovládaly dění na vrcholných soudních fórech od středověku do raného novověku. Vedle ústnosti a přímosti řízení, znamenajících, že soud si nevystačil s písemnými podklady a jednal v bezprostředním styku s účastníky, dbalo se kontradiktorního postavení obou stran. ${ }^{77}$ Opat Bonifác a Lužičtí se ve svých projevech střídali, takže objasňování skutkového stavu se odehrávalo podle scénáře, který by se dal charakterizovat jako polemika o právo (motis hinc inde verbis inter partes ac multiplicatis). Jelikož pramen mlčí o vystoupení řečníků, ač o nich míváme zmínky v listinách o majetkových sporech kláštera Hradiště, dá se usuzovat, že ani žalobce, ani žalovaní nevyužili tentokrát možnosti právního zastoupení.

Když odezněly ústní přednesy, sestoupili se šlechtičtí přísedící k poradě, aby ve shodě se středověkým principem kolektivního nalézání práva ${ }^{78}$ vydali rozhodnutí o způsobu vede-

72 JANIŠ, Zemské soudnictví, s. 204.

73 Zaznamenal již JANIŠ, Zemské soudnictví, s. 186.

74 Srv. FRIEDRICH, O kanceláři a listinách, s. 38.

75 CDB II, s. 362-364, č. 351. Blíže ELBEL, c. d., s. 42-44.

76 Jedná se o římsko-kanonický termín, který byl rozššřený v listinách 13. století, aniž by se omezoval na př́jemecký okruh kláštera Hradiště, např.: ŠEBÁNEK, J. - DUŠKOVÁ, S. (eds.). Codex diplomaticus et epistolaris Regni Bohemiae IV-1 (1241-1253). Praha: Nakladatelství Československé akademie věd, 1962 , s. 304, č. $177^{++}$, dále jen „CDB IV-1“; $C D B V$-2, s. 254, č. 636 a 637. Eviduje PACLÍK, c. d., s. 86 v pozn. Více o něm ROUMY, F. Complementum justitiae exhibere: La fortune d'une clause de chancellerie pontificale aux XIIe et XIIIe siècle. In: MAUSEN, Y. - CONDORELLI, O. - ROUMY, F. - SCHMOECKEL, M. (eds.). Der Einfluss der Kanonistik auf die europäische Rechtskultur. Bd. 4, Prozessrecht. Köln - WeimarWien: Böhlau, 2014, s. 231-252.

77 MARKOV, J. Kapitoly z dějin českého zemského soudního řizení XII.-XVII. století. Praha: Academia, 1967, s. 296-297. Pro srovnání s poměry ve středověké západní Evropě OESTMANN, P. Wege zur Rechtsgeschichte: Gerichtsbarkeit und Verfahren. Köln: Böhlau, 2015, s. 60-61, 69 a násl.

78 JANIŠ, D. Nalézání práva a zemské soudnictví v českých zemích. In: JAN, L. - JANIŠ, D. a kol. (eds.). Ad iustitiam et bonum commune. Proměny zemského práva v českých zemích ve středověku a raném novověku. Brno: Matice moravská a Historický ústav AV ČR, 2010, s. 23-67, zde s. 35 a násl. Z širší perspektivy REYNOLDS, S. Rationality and collective judgement in the law of Western Europe before the twelfth century. Quaestiones medii aevi novae, 2000, vol. 5, s. 3-19, zde s. 7 a násl. 
ní důkazů (sententia baronum). ${ }^{79}$ Usnesli se, že opat Bonifác má svůj nárok opatřit svědectvím blíže nespecifikovaného počtu lidí a že svědkové, podporující žalobu, mají splňovat předpoklad „vhodnosti“ a ,věrohodnosti“" (iudicavit ... dominum abbatem in sua actione debere producere testes idoneos et fide dignos). Ve sporech o nemovitosti se k obdobnému postupu uchyloval soud, pakliže nebylo listinných dokumentů a sami aktéŕi se nebyli schopni dohodnout, kdo a jak má svá tvrzení dokazovat. Vyžadovalo se tolik svědků, kolik odpovídalo hodnotě předmětu, o nějž se strany přely. U pozemků to bylo na Moravě ne méně než sedm osob šlechtického původu, přičemž Bonifácovi se opravdu podařilo sehnat je a prrivést ve více než dostatečném počtu před soudní tribunál (produxit ergo hos testes dominus Bonifacius abbas coram nobis). ${ }^{80}$

Mezi devíti urozenci, kteří svědčili ve Znojmě ve prospěch kanonie premonstrátů, na sebe upozorňují osobnosti ze severní části Moravy. V jejich výčtu se pak vpředu na čestných pozicích nacházejí hradští beneficiáři. ${ }^{81} \mathrm{Z}$ Olomoucka, v němž ležely dotčené klášterní statky, se dostavili komorník Bavor (v úřadě 1208-1224),82 purkrabí Záviš (1208-1222) a sudí Velíz. Z Přerova dorazil správce hradu Blud (1213) jednak s bratrem Bicenem, jednak se syny Onešem a Viktorem. Po nich se uvádí bez úřední funkce Předbor, jenž se psal snad po Tečovicích na Zlínsku (de Cetow) a jehož rod, jak se zdá, držel kolem roku 1219 purkrabství v Lukově. ${ }^{83}$ Spolu s Předborem se na závěr připomíná jistý Protiven de Vniczow. O něm se spekuluje, že zastával nějaký post v zeměpanské správě Olomoucka ve 13. století a že sídlil na statcích v osadě Uničov předtím, než se stala městem. ${ }^{84} \mathrm{~V}$ řadě jmen na sebe ale největší pozornost upoutává Velíz ve své dvojjediné roli sudího a svědka. Podle skromných poznatků, vytěžených z diplomatického materiálu, náš středověký právní řád takovou procesní situaci připouštěl, trrebaže se neslučuje s moderní ideou nestrannosti. Analogicky můžeme poukázat na konflikt, který se rozpoutal roku 1279 o hranice statků mezi hradišt'ským opatem Budišem a Albertem z Lešan. Klíčovou úlohu během přelíčení sehrál bývalý královský vilik Jan, jenž sporné majetky spravoval za vlády Přemysla Otakara II. Nejenže vypovídal ve prospěch kláštera, ale současně byl Jan ustanoven rozhodcem a jeho nález se stal podkladem pro definitivní soudní rozhodnutí. ${ }^{85}$

V právněhistorické literatuře se setkáváme s názorem, že obsah výpovědi byl ve 13. století vedlejší, na čem však záleželo, byla svědecká přísaha. Poučka, kterou před lety zfor-

79 V německé literatuře se hovoří o tzv. Beweisurteile. Viz OESTMANN, $c$. d., s. 72 a násl. včetně komentované bibliografie na s. 309 a násl.

80 MARKOV, Kapitoly z dějin, s. 160 a násl. Dále k profilu svědků v mladších normativních pramenech TÝŽ. Původ-sok a jeho místo v systému českého středověkého průvodního řízení. Sborník věd právních a státnich, 1928, roč. 28, s. 347-394, zde s. 374-375.

81 Nebude-li uvedeno jinak, vychází prosopografie včetně dat o výkonu funkce z díla JAN, Vznik zemského soudu, s přihlédnutím k HORNA, R. K dějinám moravských úredníků I. Dvorští úredníci moravští do r. 1411. Praha: Bursík a Kohout, 1922.

82 Ke komplikované identifikaci Bavorů ve Friedrichově Codexu BOLINA, P. Byl hrad Svojanov u Poličky posledním centrem tzv. úsobrnské provincie? (Př́spěvek k historii moravsko-českého pomezí II.). Časopis Matice moravské, 2005, roč. 124, č. 1, s. 3-46, zde s. 11-13 a v pozn.

83 JANIŠ, D. - KOHOUTEK, J. Královské hrady východní Moravy a jejich úloha v mocenském a správním systému ve 13. a 14. století. Archaeologia historica, 2001, roč. 28, s. 357-374, zde s. 368.

84 ŠLEZÁR, P. Období raného středověku (30. léta 6. století - 1213). In: BUREŠOVÁ, J. (ed.). Uničov. Historie moravského města. Uničov: Město Uničov, 2013, s. 45-51, zde s. 51.

$85 C D B V I-1$, s. 127-129, č. 79+. Podrobně ŠTACHOVÁ, Ke sporu hradiského opata Budiše. 
muloval Josef Markov, neplatila ale vždy. ${ }^{86} \mathrm{~K}$ výjimkám by se patrně daly připočíst mezní spory, jak naznačuje svědectví v hradišt'ském př́padě (testimonio), nebot' bylo shledáno za vyhovující i bez přísahy, po jejímž skládání není v prameni sebemenší stopy. Můžeme se domýšlet, že stejně jako v Budišově kauze z roku 1279 převážilo rovněž ve Znojmě roku 1220 racionální hledisko, kladoucí důraz na obeznámenost vyslýchaných osob s relevantními skutečnostmi (causa ... rationabiliter terminata). ${ }^{87}$ Jakmile př́sedící nabyli přesvědčení, že nárok žalobce je opodstatněný, nic už nebránilo, aby přikročili k druhému, již konečnému nálezu (cum nobis et nostris baronibus id sufficienter visum fuisset comprobatum). A tak bylo jménem Vladislava Jindřicha vyhlášeno, že lesní komplex u Domašova má náležet premonstrátům z Hradiště (nos de solita nostrae benignitatis clementia ... pleno iure fecimus possessorem).

Symbolickou tečku za řízením udělal opat Bonifác, když podle zvyklosti předstoupil před markrabího, uklonil se a odevzdal sudímu Velízovi dva denáry přísudného, což byl zvláštní poplatek, který dával žalobce na znamení, že zvítězil nad žalovanými (inclinavit ... et duos denarios, qui vulgo przisudni dicuntur, in signum causae obtentae coram nobis Veliz iudici praesentavit). ${ }^{88}$ Ačkoliv se v listině čte possessio, resp. possessor, z širšího kontextu a z prripojeného sousloví pleno iure lze vyvodit, že klášteru nebyla přiznána rrímskoprávní držba jakožto faktický stav, jehož ochranu starší české právo beztak neuznávalo, nýbrž vlastnická oprávnění v jejich plném rozsahu. ${ }^{89}$ Výraz cum utilitatibus zase napovídá,

86 MARKOV, Kapitoly z dějin, s. 161-162; TÝŽ. Piovod-sok, s. 359, 369 a násl.

87 Srv. JIREČEK, H. Slovanské právo v Čechách a na Moravě II. Od počátku XI. do konce XIII. století. V Praze: Sklad Karla Bellmanna, 1864, s. 228-229; TÝŽ. Das Recht in Böhmen und Mähren I-2. Von der ersten Nachrichten bis zum Schlusse des XII. Jahrhunderts. Prag: Carl Bellmann's Verlag, 1866, s. 129. Z kazuistiky můžeme doplnit konflikt tepelské kanonie o dvorec Nelžejov a o jeho mezníky roku 1242, kdy se zvolení rozhodci museli spolehnout na svědky. $C D B I V-1$, s. 79, č. 16: ad prefixum terminum convenientes et sibi testibus plurimis adiunctis tandem cause finem inposuerunt. Více se ví o mezní při k roku 1298, kdy se premonstráti ze Zábrdovic a Vilém z Dambořic shodli na rozhodcích, kteří výslech svědků-pamětníků spojili s př́sahou a s ohledáním sporných hranic. CDMV, s. 105, č. CIII: materiam de metis et limitibus in prefata villa Kamenecz inquirentes et inuestigantes, et circumsedentibus vicinis hominibus senioribus iuramento prius ab eisdem recepto, ipsos homines seniores nobiscum ad campum eduximus. ad cernendas et ostendendas metas. Rovněž u církevních soudů, prosazujících u nás nejpozději od 60 . let 13 . století zásadu písemnosti, máme doloženo, že při řešení nejasností ohledně průběhu hranice dvou farností sv. Petra a sv. Jakuba v Brně byly roku 1293 předkládané listiny doprovázeny z obou stran jednak př́isežnými svědectvími (testes iurati et interrogati singulariter, producti testes et interrogati responderunt), jednak prohlídkou na místě. CDM IV, s. 405-409, zde zvl. s. 406 a 407, č. CCCXX. K brněnskému případu JAN, L. a kol. Dějiny Brna 2. Stredověké město. Brno: Statutární město Brno a Archiv města Brna, 2013, s. 676 a násl. s literaturou; BOHÁČEK, M. Das römische Recht in der Praxis der Kirchengerichte der böhmischen Länder im 13. Jahrhundert. Studia Gratiana, 1967, Vol. 11, s. 273-304, zde s. 300-302.

88 O, „př́sudném“ se dozvídáme z hradišt'ských listin $C D B V-2$, s. 577, č. 858; $C D B V I-1$, s. 128 a 129, č. 79+; $C D B V I-1$, s. 131, č. $80^{++}$; $C D B V I-1$, s. 289, č. 236. JANIŠ, Zemské soudnictví, s. 193 v pozn. hypoteticky ztotožňuje poplatek s tzv. ,pomocným“, placeným soudu už od dob Statut Konrádových. Srv. dále BRANDL, V. Glossarium illustrans bohemico-moraviae historiae fontes. Brünn: C. Winiker, 1876, s. 275; JIREČEK, H. Prove - historický slovar slovanského práva. Brno: Moravská akciová knihtiskárna v Brně, 1904, s. 302; TÝŽ, Slovanské právo v Čechách a na Moravě II, s. 239-240.

89 BOHÁČEK, M. Ř́mské právo v listinné praxi českých zemí 12.-15. století. Sborník archivnich prací, 1974, roč. 24, č. 2, s. 461-486, zde s. 466 a nás1.; TÝŽ. Einflüsse des römischen Rechts in Böhmen und Mähren. Milano: Giuffre, 1975, s. 84 a násl. 
že výrok soudu se vztahoval jednak na nemovitost, jednak na veškeré př́riostky včetně př́ijmů, které plynuly z lukrativní výroby železa. ${ }^{90}$

Z koroborace CDB II 376 dále vysvítá, že naléhání hradišt'ských mnichů Vladislava Jindřicha přimělo, aby jim ještě během podzimní návštěvy Znojma vydal listinné potvrzení, které mělo uchovat trvalou památku na vyhraný spor a zabránit revindikačním snahám poražené strany. U církevních institucí tato opatrnost patřila $\mathrm{k}$ běžné péči řádného hospodáře. ${ }^{91}$ Vladislav dal vyhotovit privilegium na domašovské zboží s výměrou jeho hranic (bona cum metis), neznámo, zda a jak konkretizovanou, a nechal ho ověřit markraběcí pečetí (praesens privilegium scribi fecimus sigilli nostri munimine roborantes). Víme také, že za správnost listiny a za její odevzdání prŕíjemci nesl odpovědnost notář markraběcí kanceláře, mistr Apolinář, který asi byl Vladislavovým kaplanem a v kancelářském úřadě jej zastihujeme minimálně od roku 1213 (per manus magistri Appollinaris notarii aule nostre)..$^{92}$ Nechyběla ani sankce, běžná v markraběcích listinách, jež hrozila světským trestem za nedbání právního ujednání. ${ }^{93}$ Kdokoliv, kdo by v budoucnu klášter v jeho právech omezoval a obmyslně žaloval o jeho pozemky (per actionem calumniosam ad iudicum evocando), měl být proto odsouzen bud' k náhradě škody, nebo k pokutě deseti hřiven zlata.

\section{Ochoz lesa u Domašova}

Poté, co byl vynesen a písemně vyhotoven rozsudek, chopil se opat hradišt'ských premonstrátů Bonifác šance, aby dokonaleji zabezpečil svůj ústav před očekávanými ataky od okolních pozemkových magnátů. Obrátil se na moravského markraběte se žádostí o provedení úředního rozhraničení, které by definovalo přesný rozsah přisouzených lesních pozemků. Vladislav Jindřich vyhověl Bonifácovu prání (ad petitionem etiam abbatis) a vyslal do oblasti jako své zástupce olomoucké beneficiáře. Ke komorníkovi Bavorovi, kastelánu Závišovi a sudímu Velízovi se přidružila skupina půhončích (cum camerariis, qui vulgo pohonczi dicuntur), jíž tvořili prý Myslík z Medlova, Bohudar s bratrem Jankem z Duban a Střemen z Chudobína. I když čtveřice půhončích nemusí být smyšlená, jak se v literatuře občas evokuje, nelze se na jména upínat. S kolísající titulaturou se objevují výlučně v hradišt'ských falzech k letům 1200, 1203 a 1220, nepočítáme-li Myslíka, který se ohlašuje v pravé listině roku 1239, ale jako lovčí. ${ }^{94}$ Přítomnost hodnostářů jako byli

$90 C D B I I$, s. 413, č. 376 má př́́kladmý výčet: orta lite inter se pro quadam silva secus villas Lassczian et Domassow et montibus, ubi metallum ferri foditur, et aliis montibus, in quibus molares lapides acquiruntur, et rivulis, in quibus aurum foditur, et omnibus aliis utilitatibus. Srv. PACLÍK, c. d., s. 60.

91 O vztahu církve k listině u nás výběrově ŠEBÁNEK, J. Das Verhältnis zur Urkunde als methodischer Faktor der diplomatischen Arbeit. Sbornik praci Filozofické fakulty brněnské univerzity. Řada historická (C), 1959, roč. 8, č. 7, s. 5-19, zde s. 8 a nás1.; ŠEBÁNEK - DUŠKOVÁ, Česká listina doby premyslovské 1, s. 139 a násl.; FIALA, Z. K otázce funkce našich listin do konce 12. stol. Sborník praci Filozofické fakulty brněnské univerzity. Řada historická (C), 1960, roč. 9, č. 7, s. 5-34.

92 Liber monasterii Gradicensis, pag. 20. Srv. FRIEDRICH, O kancelářri a listinách, s. 2 a 41 . O Apolinářovi nověji ZAORAL, $c$. d., passim a WIHODA, Vladislav Jindřich, s. 121-122.

93 FRIEDRICH, $O$ kancelári a listinách, s. 34-35.

$94 C D B$ II, s. 364, č. 351 a s. 373, č. 356; FRIEDRICH, G. - KRISTEN, Z. (eds.). Codex diplomaticus et epistolarius regni Bohemiae III-2 (1238-1240). Praha: Nakladatelství Československé akademie věd, 1962 , s. 282, č. 214, dále jen „CDB III-2“. Srv. PINKAVA, c. d., s. 397; LAPÁČEK, J. Úřad a obec půhončí. Sbornik Státního okresního archivu Přerov, 2007, sv. 15, s. 5-30, zde s. 8, a méně kriticky NOVOTNÝ, V. České dějiny I-3. Čechy královské za Přemysla I. a Václava I. (1197-1253). Praha: J. Laichter, 1928, s. 599-600 a v pozn. Nepravidelnosti v listinných údajích o úruedních osobách pro 13. století kon- 
Myslík, Bohudar, Janek a Střemen je na druhou stranu pochopitelná, nebot' ztělesňovali výkonnou složku komorníkova aparátu, v němž se starali o doručování půhonů, jak lze vytušit z jejich označení. ${ }^{95}$

Někdy po 10. září 1220, když přibyla úřední delegace k Domašovu, provedla z pověření zeměpána (auctoritate nostra) symbolický akt, kterým se přenášela vlastnická svrchovanost z jedné osoby na druhou. Rituál se řídil zvykovými normami zemského práva, avšak jeho zřetelnější kontury nám unikají. ${ }^{96} \mathrm{~V}$ objezdové praxi se o něm dozvídáme znovu roku 1233 a v dalších letech, aniž by se pisatelé listin podělili o detaily. ${ }^{97}$ Jisté je, že se rituální scénář neobešel bez opata Bonifáce, který byl v zastoupení svého konventu „tělesně“ uveden do vlastnictví lesa (nomine monasterii Gradicensis facerent possessorem). Opakující se obrat facere possessorem, ${ }^{98}$ se kterým jsme se setkali v procesu nalézání práva, dovoluje na každý pád domněnku, že hradišt'ským mnichům nepostačovalo soudní rozhodnutí a že pro získání plného a nezpochybnitelného panství nad nemovitostí se vyžadovalo symbolické „předání moci“ spjaté s komisionální objížd’kou či obchůzkou. Právní jednání se tak protáhlo do dvou geograficky a časově oddělených etap, z nichž první se odbyla na zemském soudě a druhá na klášterní doméně. ${ }^{99}$

Hlubší vhled do středověké právní mentality, usilující o maximalizaci právní jistoty, skýtá v tomto směru záznam z roku 1185. Hovoří se v něm o obejití pozemků v Záběhlicích, které mezi sebou směnili zvoníci vyšehradské kapituly Krasoň a Křižan s jistým Markantem, snad románským kupcem z pražského podhradí. ${ }^{100}$ Skladatel listiny se netají inspirací čerpanou z biblické knihy Kazatel, odkud přejal verš, že „,nit trojitá se teprv nepřetrhne“" (triplex funiculus difficile rumpitur). ${ }^{101}$ Podle jeho svérázné představy byla společnost pomyslnými nitěmi práva „svazována“ a čím hustší byla pavučina, tím spíše

statují jako normální jev např. FIALA, Z. Panovnické listiny, kancelář a zemský soud za Přemysla II. (1247-1253-1278). Sborník archivních praci, 1951, roč. 1, č. 1, s. 165-294, zde s. 213; ŠPŮROVÁ, M. Identifikace svědků v listinách královské rodiny v době Václava I. a jejich vztah k panovnickému dvoru. In: DVOřÁČKOVÁ-MALÁ, D. (ed.). Dvory a rezidence ve středověku. Sborník príspěvků z kolokvia konaného 18. brezna 2005 v Historickém ústavu AV ČR ve spolupráci s Ústavem českých dějin FF UK. Praha: Historický ústav AV ČR, 2006, s. 9-19, zde zvl. s. 13-14.

95 S komentovanou bibliografií o nich LAPÁČEK, $c$. $d$. Dále NOVOTNÝ, J. Mani, půhončí a lovci (k právní a sociální diferenciaci moravské feudální společnosti). Časopis Matice moravské, 1957, roč. 76, č. 1-2, s. 3-20; MÜLLER, V. Půhončí. List z právních dějin moravských. In: FRIEDRICH, G. - KROFTA, K. BIDLO, J. (eds.). Sbornik praci historických $k$ šedesátým narozeninám dvor. rady prof. dra Jaroslava Golla. Praha: Historický klub, 1906, s. 233-245. Pro starší dobu JAN, Vznik zemského soudu, s. 70 a 237 v pozn.

96 ŽEMLIČKA, J. „Právo knížete“ a „právo země“ jako pojmy staršího středověku. Český časopis historický, 2015, roč. 113, č. 2, s. 303-345, zde s. 339; TÝŽ, Království v pohybu, s. 302.

97 FRIEDRICH, G. (ed.). Codex diplomaticus et epistolarius regni Bohemiae III-1 (1231-1238). Pragae: Sumptibus comitiorum Regni Bohemiae, 1942, s. 48, č. 47; $C D B V-2$, s. 480, č. $795^{+}, C D B V-2$, s. 506, č. $813^{+} ; C D B V-2$, s. 514, č. $818 ; S U b$ VI, s. 148 , č. 184 .

98 Srv. Slovník středovéké latiny - Latinitatis medii aevi lexicon Bohemorum. Elektronická verze, s. v. facio. [online]. Dostupné na: http://lb.ics.cas.cz/. [cit. 16. 05. 2020].

99 Podobně HRUBÝ, Tři studie, s. 13.

100 FRIEDRICH, G. (ed.). Codex diplomaticus et epistolaris regni Bohemiae I (805-1197). Pragae: Sumptibus comitiorum regni Bohemiae, 1904-1907, s. 277-279, č. 308. Srv. HRUBÝ, Tři studie, s. 67-68. Dále s bibliografií PSÍKOVÁ, J. Příspěvky k diplomatice vyšehradských listin 12. století. Archivum Trebonense, 1973, sv. 2, s. 1-43, zde s. 4-5; HLEDÍKOVÁ, Z. Ke kulturním poměrům vyšehradské kapituly počátkem 13. století. Folia Historica Bohemica, 1980, roč. 2, s. 129-173, zde s. 134-135.

$101 \mathrm{Kaz}$ 4, 12: et si quispiam praevaluerit contra unum duo resistent ei funiculus triplex difficile rumpitur. 
byli lidé nuceni, aby respektovali platnost majetkoprávních pořízení ( ut ... id, quod factum fuerat, solidum robur valitudinis obtineret). Spolu s Václavem Hrubým můžeme odůvodněně nabýt dojmu, že trojice nití je metaforou, která vyjadřuje, že řádný převod nemovitosti probíhal ve fázích a že s každou fází se úroveň právních záruk posunovala o stupeň výše. Po (1.) „,soukromém“ právním jednání mezi stranami přicházely na řadu (2.) objezd či ochoz hranice a (3.) „veřejné“ projednání věci na zemském soudě v režimu „nesporu“.

Ritualizovaným uvedením opata do majetkových práv k zalesněnému území u Domašova se ovšem pověření olomouckých hodnostář̉ nekončilo. Museli rovněž vytyčit hranici, při čemž dbali obyčejových praktik tradovaných v zemském právu (secundum terrae consuetudinem circuirent). ${ }^{102}$ Leželo na bedrech pověřených úředníků, aby zorganizovali pochod okolo lesa, jehož se měli účastnit lidé z okolí, obeznámení s krajinou. Publikum bývalo garantem právního aktu a pečovalo o udržování vzpomínky v kolektivní paměti, a proto se z jeho řad povolávali svědkové, pokud se sousedské vztahy vyhrotily a přerostly v mezní spor. Zároveň bylo výsadou obyvatel dohlížejících na průběh ochozu či objez$\mathrm{du}$, že mohli protestovat proti úrednímu postupu (contradictione vicinorum). ${ }^{103}$ Nejprve však muselo být zvoleno výchozí mezní znamení, charakterizované prostě jako prima meta. ${ }^{104}$ Důležitost tohoto stanoviště neopomenul ještě po několika staletích podtrhnout Jakub Menšík z Menštejna ve svém traktátu $O$ mezech, kde píše o „hraničníku“ a o zvyku uzpo̊sobovat jeho vzhled, aby byl už na první pohled lépe rozeznatelný: „Však hraničník se jmenuje to znamení mezní, kteréž při začátku a konci mezí se spatřuje, a obyčejně na zřetedlnějším dřiví nebo kameních se dělají.“"105

102 Právní obřad přibližují BRANDL, Staročeské právo mezní, s. 119 a násl.; JANIŠ - ŠENKÝŘOVÁ, c. d., passim; TEPLÝ, J. Př́spěvek k problematice okrsku zvaného v listinných pramenech ,circuitus“. Východočeský sborník historický, 1997, roč. 6, s. 9-32, zde s. 26 a násl. Dále srv. MALINIAK, P. Človek a krajina Zvolenskej kotliny v stredoveku. Banská Bystrica: Univerzita Mateja Bela, 2009, s. 110 a násl., nebo komparativně laděnou monografii BYLINA, S. Drogi, granice, most. Studia o przestrzeni publicznej i sakralnej w średniowieczu. Warszawa: Instytut Historii PAN, 2012, s. 53 a násl.

103 Různou míru zapojení lokální komunity při objezdech a ochozech lze pro 13. století ilustrovat na $C D B I I$, s. 66-68, č. 75; $C D B I I$, s. 393-397, č. 364; $C D B V-2$, s. 483-484, č. 797; $C D B V I-1$, s. 143-145, č. 90; EMLER, J. (ed.). Regesta diplomatica nec non epistolaria Bohemiae et Moraviae. Pars IV (1333-1346). Pragae: Sumtibus regiae scientiarum societatis Bohemiae, 1892, s. 724-725, č. 1815; CDM IV, s. 389-390, č. CCCVI; CDM V, s. 105-106, č. CIII. Shrnutí s literaturou podává ŽEMLIČKA, J. Čechy v době knižecí (1034-1198). 2. opravené a doplněné vydání. Praha: NLN, 2007, s. 194-195; TÝŽ. Počátky Čech královských (1198-1253). Proměna státu a společnosti. Praha: NLN, 2002, s. 347-348. Pro Polsko se blíže touto otázkou zabývali např. GÓRECKI, P. Communities of Legal Memory in Medieval Poland, c. 1200-1240. Journal of Medieval History, 1998, Vol. 24, No. 2, s. 127-154, zde s. 146 a nás1.; MYŚLIWSKI, G. ,Pamiętnicy“. Ludzie sędziwi jako źródła wiedzy o przeszłości na ziemiach polskich (do końca XVI w.). In: MICHAŁOWSKI, R. (ed.). Europa barbarica, Europa christiana. Studia mediaevalia Carolo Modzelewski dedicata. Warszawa: DiG, 2008, s. 113-126, zde s. 119 a násl.; MATUSZEWSKI, J. Vicinia id est ... poszukiwania alternatywnej koncepcji staropolskiego opola. Łódź: Wydawnictwo Uniwersytetu Łódzkiego, 1991, s. 22 a násl. Pro Uhry MALINIAK, c. d., zvl. s. 111-112, 117.

104 Srv. $C D B I I$, s. 364, č. 351; $C D B I I$, s. 365, 367, č. 352; $C D B I I$, s. 373, č. 356. Mimo hradišt'ský okruh je počítání mezníků zachyceno např. v $C D M V$, s. 105-106, č. CIII. Srv. MARKOVÁ, M. Hranice a hraničení ve středověké středni Evropě. Disertační práce FF UK. Praha, 2017, s. 37 a v pozn.; MALINIAK, c. d., s. 103.

105 JIREČEK, H. (ed.). Spisy právnické o právu českém v XVI-tém století. Ve Vídni: nákl. vl., 1883, s. 192. K jeho osobnosti nově STARÝ, M. Jakub Menšík z Menštejna. In: GÁBRIŠ, T. - HORÁK, O. - TAUCHEN, J. (eds.). Školy, osobnosti, polemiky. Pocta Ladislavu Vojáčkovi k 65. narozeninám. Brno: The European Society for History of Law, 2017, s. 522-537. 
V našem př́ipadě spočíval hraničník u Domašova nad potokem zvaným Olešník, nebo též Aleš. Odtud se olomoučtí beneficiáři s osadníky vydali po objektech a značkách, kterými byly klášterní statky obklopeny a vymezeny navenek (distinctionem signorum et metarum). Lze vyrozumět, že šli pěšky a že se pohybovali nejkratšími př́mými trasami (directe eundo, per directum eundo apod.). ${ }^{106}$ Během přesunů se orientovali podle hraničních bodů a linií, přihlížejíce nejen k mezníkům, at' přirozeným, nebo člověkem uměle vytvořeným, ale i k poloze vesnic (villas), pahorků (montem), vodotečí (rivulum, fluvium) a pozemních komunikací různé velikosti (semitam, viam, viam publicam). V rámci úředního šetření bylo staré značení podrobeno bližšímu ohledání ${ }^{107}$ a dle potřeby obnovováno, aby do budoucna mohlo plnit signální funkci (metas antiquas renovantes). V jazyce listiny se pro ně užívá bohemismů hranicie, kopczy a vrociscie. ${ }^{108}$

První termín znamená bud' obecně hranici, nebo jako tady zvláštní distinktivní prvky, z nichž se hranice skládá (metae, signa). Machkův etymologický výklad, který nachází spojitost se slovesem „hrabat“, by dovoloval usuzovat na podobu nějakého dělícího př́ikopu či brázdy. ${ }^{109}$ Není proto bez zajímavosti, že rituální vyorávání hraniční brázdy máme na Moravě doloženo od konce 13. století. ${ }^{110}$ Alternativní vysvětlení zase hledá původ ve slovech „hrana“, „hranatý“ a poukazuje na existenci mezníků ze dřev, klád a kamenů, sestavených či zpracovaných do hran. ${ }^{111}$ Komplikací navíc je, že v diplomatickém materiálu se „hranice“ vyskytuje synonymně s „,kopci““ a stromy. ${ }^{112}$ Hradišt’ská listina umožňuje sice jemnější analýzu, když na straně jedné rozlišuje „kopce“a „hranice“ a na straně druhé mlčí o porostech coby hraničních ukazatelích. Protože ale postrádá bližší určení, jak by měl takový mezník vypadat, pohybujeme se pořád nanejvýš v rovině hypotéz mezi hranolovitým útvarem a prŕkopem.

Snáze uchopitelné jsou „kopce“. Lze je ztotožnit s uměle navršenými hromadami zeminy, kamenů, nebo obojího, do nichž byli kvůli snazší identifikaci kladeni tzv. ,svědkové““. Míněny jsou rozličné předměty schopné odolávat dlouhodobě rozkladu, mezi kterými se neutuchající oblibě těšily keramické nádoby, fragmenty či mince. Na Domašovsku se podařilo několik ,kopcư“ s pomocí terénní prospekce zmapovat a jejich relikty jsou patrné dodnes. ${ }^{113}$ Do třetice nelze opomenout ani „úročiště“, nad kterým se ale vznášejí otazníky.

106 Rekonstrukci průběhu hranice provedl naposledy NOVÁK, J. Vymezování panství kláštera Hradisko u Olomouce ve středověku. Diplomová práce FF UPOL. Olomouc, 2019, s. 73 a násl. Navázal tak na předchozí generace regionálních badatelů, z nichž se sluší připomenout alespoň PRUCEK, Josef. ,...Meta que vulgo dicitur kopecz...“. Zprávy Vlastivédného ústavu v Olomouci, 1972, č. 154, s. 8-10; SCHULZ, J. HOSÁK, L. Příspěvek k lokalizaci lesa Střelná. Vlastivědný věstník moravský, 1966, roč. 18, č. 2, s. 235-244; FERULÍK, A. Hranice domašovského lesa. Vlastivědný věstník moravský, 1966, roč. 18, č. 1, s. 106-109. V obdobné situaci hovoří explicitně o ostensio metarum CDB III-2, s. 350-351, č. 258.

108 „Slovníček“ má JANIŠ - ŠENKÝŘOVÁ, s. 194-195.

109 MACHEK, V. Etymologický slovník jazyka českého. 5. vydání. Praha: NLN, 2010, s. 183.

$110 C D M V$, s. 105, č. CIII: desuper vnam lineam aratro cum vomere trahere iussimus.

111 NĚMEC, I. a kol. Slova a dějiny. Praha: Academia, 1980, s. 92-93. Shodně KLÁPŠTĚ, J. Proměna českých zemí ve středověku. 2. rozšíŕené vydání. Praha: NLN, 2012, s. 225-226.

$112 C D B I I$, s. 367, č. 352; CDB IV-1, s. 279, č. 171++. Srv. MARKOVÁ, M. Vymezování hranic a jejich značení v př́rodě ve středověku. In: ŠIMŮNEK, R. (ed.). Regiony - časoprostorové průsečiky? Praha: Historický ústav, 2008, s. 98-106, zde s. 101.

113 S bibliografií NOVÁK, c. d., s. 85 a násl. K archeologickému průzkumu těchto pozůstatků DOHNAL, M. - ŠÍDA, P. Historické způsoby značení pozemkových hranic a problematika tzv. mohylovitých útvarů. Archeologie ve středních Čechách, roč. 11, č. 2, s. 635-652; ŠLEZÁR, P. Sády, kopy a „výprask na 
Výraz uplatňující se zprvu jen v hradišt'ských falzech ${ }^{114}$ asi souvisí se slovesem „rokovat“ a odkazuje na prostranství, kde se uzavíraly hraniční smlouvy a kde, jak se domnívali Jireček s Brandlem, byly na památku zřizovány mezníky. ${ }^{115}$

V CDB II 376 se praví, že účelem pouti kolem domašovského lesa bylo zabránit, aby Lužičtí, nebo jiní konkurenti v oblasti Nízkého Jeseníku obtěžovali klášter nějakými úskoky či násilnostmi (per aliquam calumniam seu violentiam de coetero molestari). Právní rituál provedený za úřední asistence zavazoval do budoucna. Mniši si od něj slibovali, že přispěje k ochraně půdního fondu a zásob rudného bohatství. Protože ale hrozilo, že se na ochoz zapomene, bylo přirozené, že se v Hradišti snažili dosáhnout jeho písemné fixace. Církev, která se vyznačovala kladným postojem k písemnostem, mívala ve zvyku zachytit akt rozhraničení na pergamen, díky čemuž se o události dozvídáme na stránkách moderních diplomatářù a regestářu. ${ }^{116}$ Potíž však je, že z dochovaného padělku si nelze učinit o věci jasnější úsudek, a proto se omezíme na předpoklad, že nějaký záznam o hraničním průvodu kolem domašovského lesa opravdu vznikl a že byl k dispozici v klášterním archivu v Hradišti.

Ani znojemský soud roku 1220, ani ochoz lesa u Domašova nepřinesly definitivní rozuzlení majetkových různic, do kterých byl zatažen premonstrátský klášter Hradiště, když obhajoval na Olomoucku proti ostatním kolonizátorům svá pozemkově-vrchnostenská práva. Písemnost CDB II 376, tvořící pramennou základnu pro naše zkoumání, ale žádné další informace o těchto pohnutých dějích neposkytuje. Nemá tudíž smysl pouštět se do jejich popisu. Lepší bude pokusit se o krátkou rekapitulaci dosažených poznatků.

\section{Závěrem}

V mikrosondě do právních dějin premonstrátského kláštera Hradiště u Olomouce, v níž jsme se snažili poodhalit zákoutí mezního sporu o církevní pozemky u Domašova kolem roku 1220, jsme pod drobnohled umístili falešnou listinu CDB II 376, která je výsledkem čilých padělatelských aktivit, pěstovaných v hradišt'ském skriptoriu od druhé poloviny 13. věku. Vytěžit diplomatický materiál starobylé moravské fundace se nabízelo jednak proto, že je proslulý svou mnohomluvností, se kterou líčí právní reálie, jednak proto, že klášter jakožto kolonizátor soustavně zabředával do konfliktů s okolními pozemkovými vrchnostmi, čímž se jeho osudy stávají výborným odrazovým můstkem pro výzkum mezního práva $\mathrm{v}$ archaických dobách. Aby bylo možno osvětlit jeden z dlouho opomíjených aspektů středověkého právního života, na který tu narážíme, bylo ovšem nutno přezkoušet faktografickou přesnost listinného padělku. Za nástroj pramenné kritiky byla zvolena komparace s listinami a aktovými záznamy, vypovídajícími o praktikách mezního práva, které se v našich končinách zachovaly z doby přemyslovské. V jednotlivostech se posléze projevilo, k čemu se klonila literatura už dříve, že falzum dobře zapadá do našich povšechných

pamětnou“. Hranice ve středověké krajině Drahanské vrchoviny. Vlastivědný věstník moravský, 2007, roč. 59 , č. 2 , s. $155-161$.

115 JIREČEK, O soudu mezním, s. 172; BRANDL, Staročeské právo mezní, s. 126-127. Přehledově LEŚNY, J. Uroczysko. In: LABUDA, G. (ed.). Słownik starożytności słowiańskich. Encyklopedyczny zarys kultury Stowian od czasów najdawniejszych do schyłku wieku XII. Tom VI. (T-W). Wrocław: Zakład Narodowy imienia Ossolińskich, 1977, s. 271-272 včetně bibliografie. 
vědomostí o správě veřejných záležitostí v prvních dekádách 13. století. Opodstatněnost územních aspirací, podložených písemně, musel koneckonců uznat i odpůrce kláštera premonstrátů, Albert ze Šternberka.

V hradišt'ské listině CDB II 376 jsme dokázali postihnout tři právně-historicky významné momenty, které byly do hloubky probrány. Prvním z nich bylo soudní zasedání ve Znojmě, kde se v zářijových dnech roku 1220 setkali moravští předáci, aby rozhodli o vlastnických poměrech v zalesněném teritoriu, které přiléhalo $\mathrm{k}$ Domašovu u Šternberka a které zahrnovalo lukrativní naleziště železné rudy. Žalující stranu ztělesňoval hradišs’ský opat Bonifác, kdežto žalovanými byli obyvatelé vsi Lužice, žijící v sousedství lesa. Zemskému soudu, usměrňovanému tehdy obvyklými zásadami obžalovací, ústnosti, př́mosti a kontradiktornosti, předsedal moravský markrabě Vladislav Jindřich. Vedení řízení se zhostil olomoucký sudí Velíz a spolu s ním se úlohy přísedících ujali nejmenovaní baroni, kteří se nejprve usnesli, že žalobce má postavit vhodné svědky, aby poté, co vyslechli svědecké výpovědi, předmětný les přisoudili opatovi a mnichům z Hradiště.

Druhou právně relevantní skutečností, jež k př́ípadu upoutává zájem historika, je konfirmace vystavená moravským zeměpánem Vladislavem Jindřichem na žádost hradišt'ských premonstrátů. Byla-li soudní pře korunována úspěchem, potom listinné stvrzení mělo směřovat k upevnění vlastnické pozice kláštera na Domašovsku a k zabránění budoucím úchvatům, prováděným na úkor církevního zboží. Dávno ztracené privilegium, které si podle všeho našlo cestu do falza CDB II 376 a které bylo i jeho hlavním inspiračním zdrojem, obsahovalo průběh sporu na zemském právu. Na znamení právoplatnosti bylo opatřeno markraběcí pečetí a jak lze vyčíst mezi řádkami padělku, s nímž si musíme vystačit, za bezvadnost originální předlohy a za její odevzdání př́ijemci z Klášterního Hradiště odpovídal mistr Apolináŕ, o kterém máme prokázáno, že byl Vladislavův notář a kaplan přinejmenším od roku 1213.

Do třetice listina poučuje o rituálních aktech, tkvějících svými kořeny v obyčejovém právu Čech a Moravy, jež nakládání s nemovitostmi, les u Domašova nevyjímaje, zahalovaly do typicky středověkého hávu. V časovém odstupu od znojemských rokování, jehož délku lze těžko odhadnout, se hradišstský představený Bonifác obrátil na Vladislava Jindřicha, aby vyslal olomoucké beneficiáře na lesní pozemky, o něž se předtím klášter dohadoval s Lužickými. Delegace byla složena z komorníka, kastelána, sudího a čtveřice půhončích, vesměs osob spolehlivě dohledatelných v pramenech, a když dorazila do cíle, stanula před dvěma úkoly. Předně bylo třeba Bonifáce uvést do „tělesného“ vlastnictví k půdě, které se symbolicky přenášelo na nabyvatele vykonáním slavnostního obřadu, komentovaného v listinách dosti vágně. Nato se úředníci z Olomoucka vydali na pěší obchůzku kolem domašovského lesa. Pohybovali se v doprovodu zdejších usedlíků a kráčeli přitom nejkratšími možnými spojnicemi mezi hraničními značkami, které nejen ohledávali, ale i rekonstruovali, aby meze nadále mohly sloužit církevním majitelům. Pokud dopřejeme víry CDB II 376, čekalo se od ochozu, že zabezpečí mnichy před úskoky a násilnostmi, jež premonstrátům hrozily od jejich sousedi̊.

Př́iběh domašovského lesa je nesmazatelně vepsán v textové tradici hradišt'ského kláštera, pro kterou je však příznačné, že ponechává široký prostor spekulacím. Pokud bychom se přesto měli odvážit hypotézy a zároveň shrnout dosavadní úvahy, zdá se nejpravděpodobnější, že vývoj probíhal ve třech fázích: (1.) Na počátku byla listinná konfirmace soudního rozhodnutí, přijatého ve Znojmě roku 1220. (2.) Následoval jeden či více 
pamětních záznamů, pořízených v těsné návaznosti na komisionální obhlídku klášterního lesa u Domašova. Sem byly pojaty hraniční ukazatele, peripetie a osoby podílející se na rozhraničovacím aktu. (3.) Na konci řady stojí falzum CDB II 376, které jako jediné máme dnes v ruce. Sestaveno bylo podle starších dokumentů chovaných v Hradišti, a to proto, že si jeho sepsání vynutila nová právní situace, do níž se dostal konvent premonstrátů v pokročilém 13., resp. v počínajícím 14 . století.

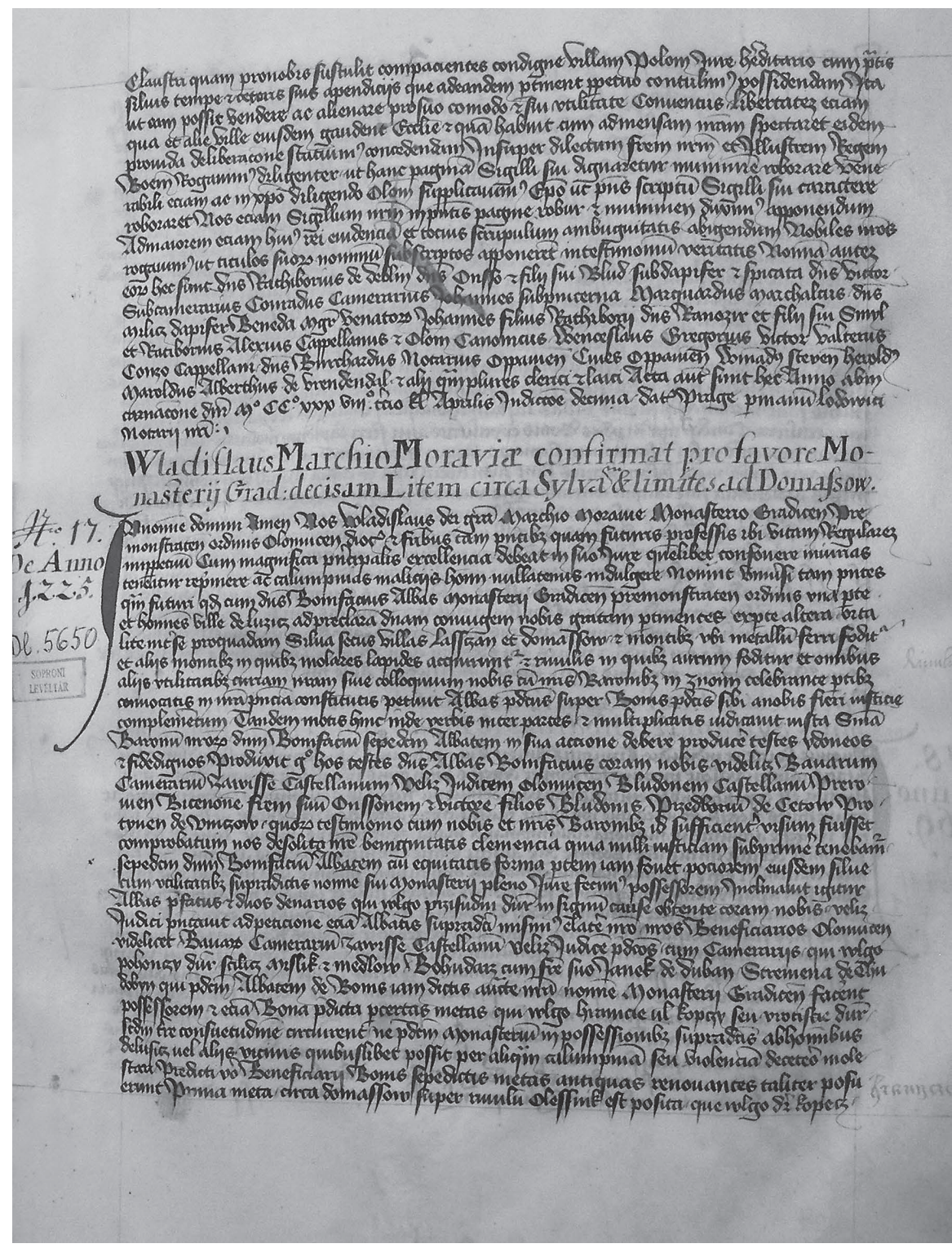

Liber monasterii Gradicensis ... Klášterni archiv v Csorne, pag. 19. 


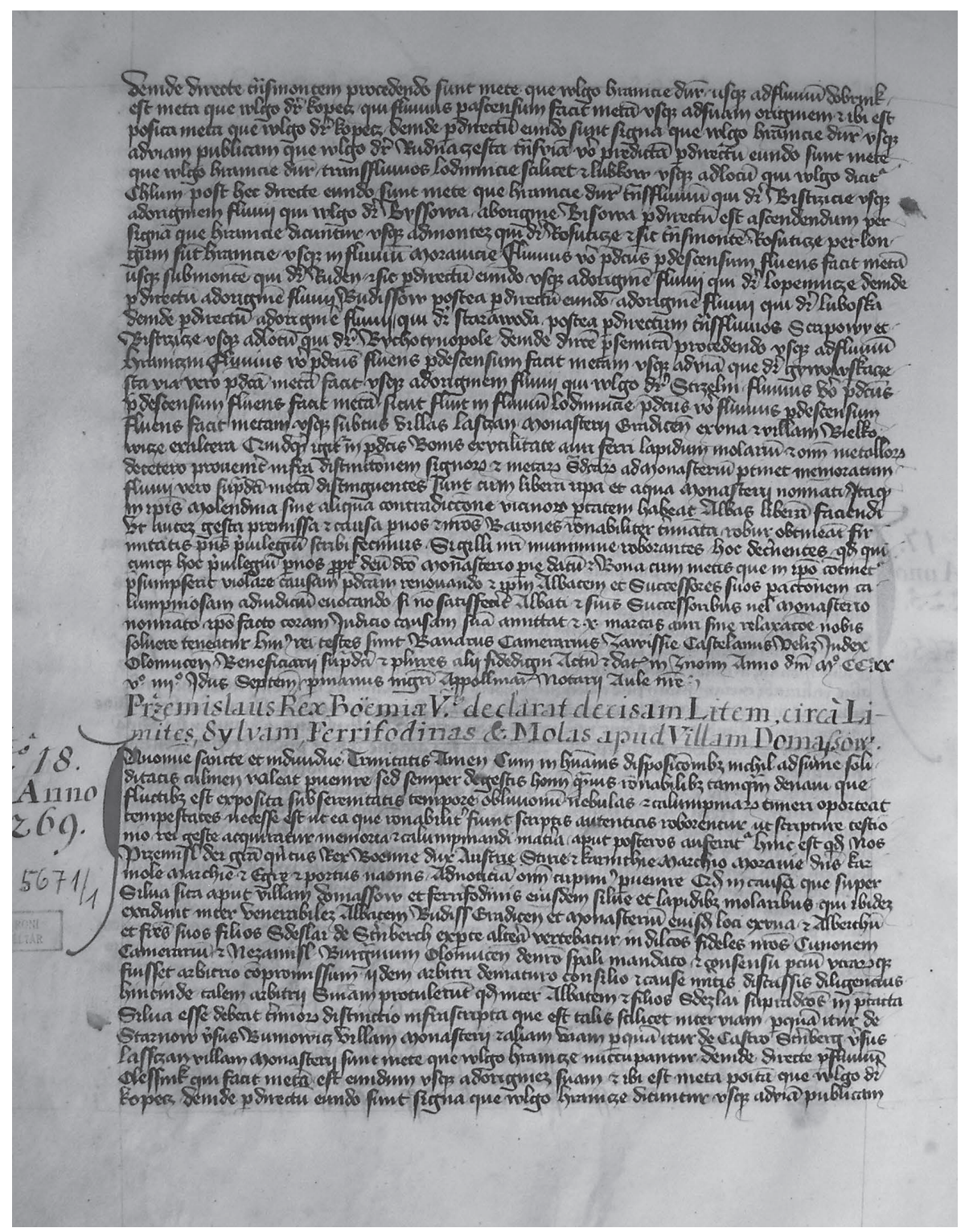

Liber monasterii Gradicensis ... Klášterní archiv v Csorne, pag. 20. 